\title{
Feline low-grade alimentary lymphoma: an emerging entity and a potential animal model for human disease
}

\author{
Mathieu V Paulin ${ }^{1 \dagger}$, Lucile Couronné $2,3,4+$, Jérémy Beguin ${ }^{5}$, Sophie Le Poder ${ }^{6}$, Maxence Delverdier ${ }^{7}$, \\ Marie-Odile Semin 7 , Julie Bruneau ${ }^{8,9}$, Nadine Cerf-Bensussan ${ }^{3,10}$, Georgia Malamut ${ }^{11,12}$, Christophe Cellier ${ }^{11,12}$, \\ Ghita Benchekroun ${ }^{5}$, Laurent Tiret ${ }^{13}$, Alexander J German ${ }^{14}$, Olivier Hermine $e^{2,3,4}$ and Valérie Freiche ${ }^{5^{*}}$
}

\begin{abstract}
Background: Low-grade alimentary lymphoma (LGAL) is characterised by the infiltration of neoplastic Tlymphocytes, typically in the small intestine. The incidence of LGAL has increased over the last ten years and it is now the most frequent digestive neoplasia in cats and comprises 60 to $75 \%$ of gastrointestinal lymphoma cases. Given that LGAL shares common clinical, paraclinical and ultrasonographic features with inflammatory bowel diseases, establishing a diagnosis is challenging. A review was designed to summarise current knowledge of the pathogenesis, diagnosis, prognosis and treatment of feline LGAL. Electronic searches of PubMed and Science Direct were carried out without date or language restrictions.

Results: A total of 176 peer-reviewed documents were identified and most of which were published in the last twenty years. 130 studies were found from the veterinary literature and 46 from the human medicine literature. Heterogeneity of study designs and outcome measures made meta-analysis inappropriate. The pathophysiology of feline LGAL still needs to be elucidated, not least the putative roles of infectious agents, environmental factors as well as genetic events. The most common therapeutic strategy is combination treatment with prednisolone and chlorambucil, and prolonged remission can often be achieved. Developments in immunohistochemical analysis and clonality testing have improved the confidence of clinicians in obtaining a correct diagnosis between LGAL and IBD. The condition shares similarities with some diseases in humans, especially human indolent T-cell lymphoproliferative disorder of the gastrointestinal tract.

Conclusions: The pathophysiology of feline LGAL still needs to be elucidated and prospective studies as well as standardisation of therapeutic strategies are needed. A combination of conventional histopathology and immunohistochemistry remains the current gold-standard test, but clinicians should be cautious about reclassifying cats previously diagnosed with IBD to lymphoma on the basis of clonality testing. Importantly, feline LGAL could be considered to be a potential animal model for indolent digestive T-cell lymphoproliferative disorder, a rare condition in human medicine.
\end{abstract}

Keywords: Comparative oncology, Cat, Inflammatory bowel disease, Human indolent digestive T-cell lymphoproliferative disorder

\footnotetext{
* Correspondence: valerie.freiche@vet-alfort.fr

${ }^{\dagger}$ Mathieu $V$ Paulin and Lucile Couronné contributed equally to this work.

${ }^{5}$ Internal Medicine Department, Université Paris-Est, École Nationale

Vétérinaire d'Alfort, 7 Avenue du Général de Gaulle, 94700 Maisons-Alfort,

France

Full list of author information is available at the end of the article
}

(c) The Author(s). 2018 Open Access This article is distributed under the terms of the Creative Commons Attribution 4.0 International License (http://creativecommons.org/licenses/by/4.0/), which permits unrestricted use, distribution, and reproduction in any medium, provided you give appropriate credit to the original author(s) and the source, provide a link to the Creative Commons license, and indicate if changes were made. The Creative Commons Public Domain Dedication waiver (http://creativecommons.org/publicdomain/zero/1.0/) applies to the data made available in this article, unless otherwise stated. 


\section{Background}

Lymphoma is a clonal expansion of neoplastic lymphocytes in solid organs and is the most common feline neoplasm [1-7]. Feline lymphomas are usually classified according to anatomical location, with various types recognised including mediastinal, multicentric, and extra-nodal. A final type, alimentary lymphoma (AL) targets the gastrointestinal tract with variable involvement of extra-intestinal sites including lymph nodes, liver, spleen $[3,4,7,8]$. Not only is this the most common anatomical form of lymphoma (50 to $75 \%$ ), it is also the most common alimentary neoplasia in cats [1-5, 8-19].

Several subtypes of AL can be defined according to the histological grade (low, intermediate or high), cell size (small or large) and phenotype ( $\mathrm{T}$ or $\mathrm{B}$ ) of the neoplastic lymphocytes [6, 8, 14, 18, 20-23]. Originally, lymphomas were classified according to the World Health Organization (WHO) scheme into Enteropathy-Associated T-cell Lymphoma (EATL) type 1 and 2 . Recent studies in human medicine indicate that EATL consists of two diseases that are morphologically and genetically distinct. They also differ in how frequently they are associated with coeliac disease [24]: EATL type I (80-90\% of EATL) is strongly associated with coeliac disease, has usually a large-cell or pleomorphic cytology and may express CD30 [24]. EATL type II (10-20\% of EATL) is less frequently associated with coeliac disease and is characterised by monomorphic population with frequent expression of CD56 [24]. EATL type II has been recently renamed as Monomorphic Epitheliotropic T-cell Lymphoma (MEITL), calling into question its relationship with classical EATL and implying that it might be best to consider it as a separate entity [25].

The current classification system for this disease has been defined by Moore et al. and distinguishes two entities [6]: first, "mucosal lymphomas" which are usually low-grade forms of alimentary lymphoma (LGAL) and are predominantly of small T-cell type (nuclear diameter $<2$ red cell diameters) that Moore et al. found to match the WHO entity EATL type II. Second, "transmural lymphomas", which are more frequently high-grade alimentary lymphomas (HGAL) and are composed of small or large cells that can be of B- or T-cell type. Transmural intermediate to large-sized T-cell lymphomas would match the WHO entity EATL type I for Moore et al. When of large T-cell type, these lymphomas are mostly Large Granular Lymphocytic Lymphomas (LGLL) and express the cytotoxic granule protein, granzyme B. LGLL is less frequent, but the most aggressive subform of $\mathrm{AL}$ and can be considered as a separate histological sub-classification of AL with LGAL and HGAL [8, 26, 27].

LGAL may be the most common subtype in cats, representing 60 to $75 \%$ of $\mathrm{AL}$ [18-20]. However, the real incidence is not accurate since it is based upon a few small sample studies. Moreover, for unknown reasons, it appears to be an emerging entity with an increasing incidence over the last ten years $[8,28]$. The aim of this review is to provide an overview of current knowledge regarding the aetiology, clinical and biological presentation, diagnosis, treatment and prognosis of LGAL. Comparisons of this condition with the rare human disease, indolent T-cell lymphoproliferative disorder (LPD) of the gastrointestinal tract, will also be highlighted.

\section{Methods}

Electronic searches of PubMed and Science Direct were carried out without date or language restrictions. A total of 176 peer-reviewed documents were identified and most of which were published in the last twenty years. 130 studies were found from the veterinary literature and 46 from the human medicine literature. Heterogeneity of study designs and outcome measures made meta-analysis inappropriate.

\section{Results \\ Aetiopathogenesis}

The aetiopathogenesis of feline LGAL is poorly understood. Several factors have been implicated as possible causes, but their involvement remains inconclusive, particularly considering the relationship with the AL histological grade and phenotype [14].

\section{Feline retroviruses}

An infectious aetiology has been suggested because the risk of developing AL is greater in cats infected by feline retroviruses (feline leukaemia virus [FeLV] or feline immunodeficiency virus [FIV]). However, this hypothesis has been challenged on account of the fact that most lymphocytic cancers in all species are non-retroviral-associated [29].

FeLV infects the lymphoid tissue, intestine and bone marrow [3], and is suspected to be a major risk factor in development of leukaemia and lymphoma in cats, particularly T-cell lymphoma with a mediastinal location [30, 31]. Immunohistochemical studies have identified that 50 to $70 \%$ of all feline lymphomas are positive for FeLV [3, 7, 13, 32, 33] and its presence is associated with poor prognosis in all lymphoma subtypes [2, 34]. The exact mechanisms by which FeLV causes neoplastic transformation are not known but could be related to virus genome insertion, resulting in modulation of neighbouring oncogenic or tumour suppressor gene expression [30, 35]. Further, in contrast to multicentric lymphoma, the exact role of FeLV in development of AL is also unclear since it is inconsistently identified in AL cases [34, 36, 37], and many forms of lymphoma, including $\mathrm{AL}$, can effectively develop without exposure to FeLV in pathogen-free cats $[2,10]$. Over the past 30 years, circulating FeLV antigen has been observed in 
2 to $30 \%$ of cats with AL $[3,20,36-38]$ but, more recently, most AL cases do not have circulating FeLV antigen [13]. One possible explanation for this is the success of widespread implementation of test and vaccination programmes, which have helped to decrease FeLV prevalence in cats $[2,5,20,39]$.

Using immunohistochemistry (IHC), only $3 \%$ of AL tumours are positive for FeLV [20,37, 40] although, in one study involving 25 cats with AL, alimentary lymphoma provirus sequences were detected in approximately $1 / 3$ of B-cell AL and almost 2/3 of T-cell AL [36]. These latter findings suggest that FeLV may be present in a latent or replication-defective form in some cases $[36,40]$. In contrast, no provirus form of FeLV was detected in another study involving $32 \mathrm{AL}$ cases, 30 of which were FeLV-antigen-negative [38]. The discrepancies between both studies could be due to variability in assay sensitivity, with the higher prevalence of FeLV provirus detection in the first study possibly result of use of a highly-sensitive semi-nested PCR assay [36]. Additional epidemiological, functional and highly-sensitive molecular analyses are therefore required to clarify the role that FeLV plays in AL. In particular, it would be helpful to clarify the association between the presence of FeLV and different histological grades of AL, especially LGAL given its increasing prevalence.

Like human (HIV) and simian (SIV) immunodeficiency viruses [41-43], FIV can induce indirect immune dysregulation, resulting in partial loss of antitumoral immunity and ultimately promoting tumour development $[3,44,45]$. Studies have shown that FIV infection may increase the risk of developing various types of lymphoma, including AL $[7,14,34,46]$. In addition, components of the FIV genome were detected in tissues from 7 of $8 \mathrm{AL}$ that had developed in FIV-positive cats [47], 4 and 3 of which were B- and T-lymphoma, respectively. Various parts of the gastrointestinal tract were affected, and there was mesenteric lymph node involvement in 3 cats. However, unfortunately histological grade was not determined.

A final virus that has been implicated as an aetiological agent is the panlymphotropic Felis catus gammaherpesvirus 1 (FcaGHV1), and this virus is known to infect at least one quarter of cats. A possible role is plausible given the detection of two human gammaherpesviruses (Epstein-Barr and Kaposi's sarcoma-associated viruses) in some lymphoma cases $[48,49]$. However, in one study, neither detection of FcaGHV1 DNA nor whole blood virus load was related to a diagnosis of lymphoma [50]. That said, the presence of circulating FcaGHV1 DNA was associated with significantly shorter survival compared with FcaGHV1 qPCR negative cases [50]. A limitation of this study was the fact that the criteria used to recruit lymphoma cases excluded lymphocytic low-grade gastrointestinal lymphoma and, as a consequence, further studies are required.

\section{Bacterial infections}

Over the last two decades, bacterial mucosal colonisation, particularly involving argyrophilic organisms such as Helicobacter spp., has been highlighted as a potential oncogenic factor in feline gastric cancer as a result of chronic antigenic stimulation [51, 52]. Helicobacter pylori infection is strongly associated with development of adenocarcinoma and mucosa-associated lymphoid tissue (MALT) lymphoma in humans [53, 54]. The gastric mucosa of dogs is often colonised by non-Helicobacter pylori helicobacters. Although their pathogenic significance in dogs is poorly understood, there is evidence of Helicobacter spp. infection in laboratory beagle dogs resulting in gastric lymphoid follicle formation that is considered a precursor of MALT lymphoma in humans [55].

Gastric Helicobacter heilmannii (Hhe) strains were reported to promote feline gastric lymphoma in one study involving 47 cats, where respectively 14 out of 16 and 2 out of 16 lymphoblastic and lymphocytic lymphomas were positive for Hhe organisms (especially the Hhe2 and Hhe 4 strains) [52]. Amongst a population of 33 low-grade T-cell epitheliotropic small intestinal lymphomas, mucosa-invasive bacteria and serosal colonisation have been identified in $18 \%$ and $11 \%$ of cases, respectively. In comparison, of the 17 high grade small intestinal lymphomas, 14 (82\%) were associated with mucosal-invasive bacteria, serosal colonisation was evident in 10 (57\%), and intravascular bacteria were observed in 5 (29\%) [56]. In contrast, bacteria were not detected in any of the cases of LGAL [56]. However, it remains unclear whether invasive bacteria might trigger the development of AL or are instead opportunistically colonising the damaged mucosa after AL has developed [56]. Further prospective studies are required to establish whether lymphomatous mucosa could be permissive for bacterial colonisation in this context.

\section{Chronic inflammation}

It is suggested that chronic inflammation can increase the risk of developing $\mathrm{AL}$, not least given that concurrent inflammatory bowel disease (IBD) has been described in up to $60 \%$ of AL cases [57-61], with many hypothesising that IBD may precede or promote digestive neoplasia $[20,38,59,62-66]$. It has also been suggested that certain forms of human coeliac disease might actually represent low-grade intraepithelial T-cell malignant lymphoma rather than being a reactive $\mathrm{T}$-cell proliferation $[67,68]$, and this has also been suggested for feline lymphoplasmacytic enteritis [20].

However, to date, there is no published veterinary evidence demonstrating the development of AL subsequent 
to chronic intestinal inflammation. In one recent study, MDR1 gene expression (MDR1, which encodes an efflux pump membrane protein) and cyclo-oxygenase 2 (COX2) were assessed in cats with chronic enteropathies, and were found to be greater in cats with LGAL than in cats with IBD [63]. It is not possible to determine if increased MDR1 expression plays a role in the aetiopathogenesis of feline IBD and LGAL but these results could explain the necessity of a more aggressive therapy in the lymphoma [63]. However, human patients with IBD show reduced expression of MDR1 in the colon and overexpression of COX2 may be associated with cell proliferation and angiogenesis $[69,70]$.

\section{Other factors}

Chronic cigarette smoke exposure and geographic factors have been suggested to promote AL but reported cases were not further subdivided based upon grade $[8$, 11, 14, 71]. Dietary factors have also been implicated in the development of LGAL, although this is controversial, because there is no direct evidence for it [11, 29]. Further studies are required to clarify the role played by all such factors.

\section{Clinical presentation}

\section{Signalment}

LGAL usually affects ageing cats (median age 13 years) $[8,28,59,60,72-74]$, and some studies have suggested that male cats are predisposed $[4,11,20,40,60]$. The role of breed is less clear; to date, no specific association has consistently been found between breed and LGAL in cats, although domestic shorthair and Siamese are over-represented in some studies of AL, [59, 60, 73].

\section{Clinical signs}

LGAL has a chronic progressive course over weeks or months, with clinical signs (in order of frequency) including: weight loss (80-90\%), vomiting (70-80\%), anorexia $(60-70 \%)$, diarrhoea (50-65\%), and to a lesser extent, icterus, splenomegaly, polydipsia/polyuria and lethargy [2, 3 , $7,8,14,38,59,61,62,72,75-78]$. These signs are not pathognomonic and overlap with other alimentary and indeed non-alimentary diseases. Therefore, differential diagnosis requires excluding metabolic diseases, endocrinopathies, inflammatory diseases such as feline triaditis, infectious processes, and other neoplastic diseases. Given the fact that LGAL mainly affects older cats, potential comorbidities may complicate the clinical features. However, the major diagnostic challenge faced by clinicians is distinguishing LGAL from IBD (see Table 4) and other forms of AL. It is suggested that abdominal palpation can help because, in contrast to LGAL, aggressive forms of AL are more commonly associated with abdominal mass lesions, lymphadenomegaly, peritonitis or ascites
$[1,3,7,77]$. Nevertheless, the findings of abdominal palpation do not reliably distinguish IBD and $\mathrm{AL}[2,8,17]$. When LGAL is involved, thickened bowel loops may be identified, although this can also be a non-specific finding $[8,15]$. Finally, it should be noted that abdominal palpation may also be normal in cats with LGAL [79].

\section{Gastrointestinal location}

In LGAL, lesions are diffuse rather than localised, and can be focal or multiple, affecting any component of the gastrointestinal tract including the stomach, small intestine or large intestine as well as the mesenteric lymph nodes, liver or spleen $[2,11,14,38,59,73]$. Although all sections of the gastrointestinal tract can be affected by LGAL, the most common sites include the jejunum and the ileum, followed by the duodenum [6, 20, 59]. Gastric involvement is uncommon for this type of $\mathrm{AL}$ (see Table 1) $[1,6,15,20,59,74,80,81]$.

\section{Diagnosis}

As mentioned above, the clinical signs of LGAL are not pathognomonic making diagnosis challenging. During diagnostic investigations, metabolic diseases, endocrinopathies, infectious diseases, chronic cholangitis, pancreatitis, and exocrine pancreatic insufficiency should first be ruled out using clinicopathological testing and diagnostic imaging $[79,82]$. Thereafter, LGAL should be differentiated from other gastrointestinal tract diseases such as food-responsive enteropathy (FRE) and IBD. Whilst dietary trials can usually eliminate FRE as a possible cause, distinguishing LGAL from IBD (such as lymphoplasmacytic enteritis [LPE] or eosinophilic enteritis [EE]) is more challenging because clinical signs, results of clinical pathology, diagnostic imaging findings, and even histological features can overlap [8, 11, 15, 60, 83-85]. Ultimately, more advanced diagnostic techniques such as immunohistochemistry and PCR for Antigen Receptor Rearrangement (PARR) are required to confirm the diagnosis.

\section{Paraclinical data}

Extensive tests are often required to distinguish LGAL from other diseases, and a typical investigation would involve haematology, serum biochemistry, urine and faecal analyses, total thyroxine concentration, diagnostic imaging and intestinal biopsies. Cats should also be tested

Table 1 Segments of the gastrointestinal tract affected by lowgrade alimentary lymphoma (LGAL)

\begin{tabular}{lll}
\hline Segments of the small intestine & Prevalence & Study \\
\hline Duodenum & $83 \%(10 / 12)$ & Lingard et al. [59] \\
Jejunum & $100 \%(15 / 15)$ & Lingard et al. [59] \\
& $86 \%(43 / 50)$ & Fondacaro et al. [20] \\
Ileum and ileocaecocolic junction & $93 \%(13 / 14)$ & Lingard et al. [59] \\
\hline
\end{tabular}


for FeLV and FIV, given the previously-reported associations with AL [75], and serum folate and cobalamin concentrations should be measured to determine the presence of malabsorption.

\section{Biomarkers}

Biomarkers that have been used in cases of AL are summarised in Table 2. To the authors' knowledge, no study has yet demonstrated the ability of paraclinical data to differentiate LGAL from IBD. However, failure to recognise and correct hypocobalaminaemia is known to delay clinical recovery, even when specific therapy for AL or IBD is instituted [82, 86]. Hypoalbuminaemia is reported in $70 \%$ of cats with $\mathrm{AL}, 49 \%$ with LGAL, and $77 \%$ with IBD respectively $[20,87]$. The reason why hypoalbuminaemia is less common in LGAL, compared with other types of AL, is not known but might reflect the fact that mucosal integrity is preserved until later in the disease process $[2,8,14]$. In dogs, cytokine IL6 suppresses albumin synthesis and may be released by neoplastic cells [88], and this might contribute to the progressive hypoalbuminaemia observed in AL [88, 89]. Previous studies have documented the prevalence of hypocobalaminaemia in cats with gastrointestinal disease, with approximately a third of IBD cases being affected [82, 83, 87, 90-93]. Between 50 and $80 \%$ of LGAL are associated with hypocobalaminaemia (Ref.: > $290 \mathrm{ng} / \mathrm{L}$ ) [2, 8, 11, $72,75,83,87,90,94]$. Not only is hypocobalaminaemia of diagnostic and prognostic significance, it can also exacerbate signs of diarrhoea, vomiting, anorexia, and weight loss, as well as causing weakness when severe.

\section{Ultrasonography}

Abdominal ultrasonography allows reliable detection of focal or diffuse thickening as well as loss of the normal layered appearance of the gastrointestinal wall (Fig. 1) $[15,95]$. In addition, this imaging modality may reveal other LGAL-associated lesions, such as mesenteric lymphadenomegaly, hepatomegaly and splenomegaly [2]. The most common ultrasonographic finding is a diffuse thickening of muscular layer in the small bowel, and this characteristic is observed in $50-80 \%$ of cases $[15,59,77$, 95-97]. Unfortunately, given that this is also commonly observed in feline patients with IBD [98], ultrasonographic distinction between LGAL and IBD is not possible (Fig. 2 and Table 3). For example, in one study involving 22 cats with FRE, 17 with IBD and 17 with AL, there were no significant differences in ultrasonographic findings between the three groups [82]. Moreover, ultrasonography is less sensitive for the detection of small lesions of the gastrointestinal tract than is endoscopy [2]. Therefore, LGAL can never be excluded on the basis of a normal ultrasonographic examination and histological analysis is always required to make a definitive diagnosis $[2,95]$.

Thickening of the gastrointestinal wall is the most common lesion observed in AL (Fig. 2) [2]. However, although reference measurements for wall thickness have been reported in cats, clear diagnostic cut-points for either LGAL or IBD have not been reported $[95,99]$. Potentially of more utility, is the identification of a thickened muscularis propria, which might be twice as thick as that seen in healthy cats [15]. Typically, the ratio of muscularis width to submucosal width in calculated, with measurements $\geq 0.5$ being considered abnormal $[15,95]$. This feature is reported to be common in feline LGAL $[15,82,95]$, although it is not pathognomic because it is also reported in IBD [15, 82], particularly in eosinophilic enteritis (EE) [100]. That said, older cats with ultrasonographic evidence of muscularis propria thickening are more likely to have $\mathrm{AL}$ versus IBD $[78,95]$.

Table 2 Description and prevalence of paraclinical data abnormalities reported in alimentary lymphoma (AL)

\begin{tabular}{|c|c|c|c|c|}
\hline \multirow[t]{2}{*}{ Data } & \multirow[t]{2}{*}{ Description } & \multirow[t]{2}{*}{ Paraclinical data } & \multicolumn{2}{|l|}{$\mathrm{AL}$} \\
\hline & & & Cases & Prevalence \\
\hline Albumin & $\begin{array}{l}\text { Biomarker of gastrointestinal } \\
\text { protein loss [87] }\end{array}$ & Decreased [87] & LGAL & $49 \%(21 / 43)[20]$ \\
\hline \multirow[t]{2}{*}{ Cobalamin (Vitamin B12) } & \multirow{2}{*}{$\begin{array}{l}\text { Biomarker of } \\
\text { absorption }[8,72,83,92,170]\end{array}$} & \multirow[t]{2}{*}{ Decreased [87] } & LGAL & $50-80 \%[2,8,11,72,75,83,87,90,94]$ \\
\hline & & & $\mathrm{AL}$ & $35,3 \%(6 / 17)$ whose 12 LGAL [77] \\
\hline \multirow[t]{2}{*}{ Folate (Vitamin B9) } & \multirow{2}{*}{$\begin{array}{l}\text { Biomarker of absorption } \\
\text { and dysbiosis }[8,72,83,86,92,170]\end{array}$} & \multirow{2}{*}{$\begin{array}{l}\text { Increased } \\
\text { or decreased }[82,87]\end{array}$} & LGAL & $37 \%(10 / 27)>21.6 \mathrm{ng} / \mathrm{ml}[72]$ \\
\hline & & & $\mathrm{AL}$ & $31 \%(4 / 13)<9.7 \mathrm{ng} / \mathrm{ml}[83,87]$ \\
\hline Lactate dehydrogenase (LDH) & $\begin{array}{l}\text { Biomarker of } \\
\text { cellular necrosis [171] }\end{array}$ & Increased [172] & LGAL & $47 \%(9 / 19)[172]$ \\
\hline $\begin{array}{l}\text { Fecal a1 proteinase inhibitor } \\
\text { concentration }\end{array}$ & $\begin{array}{l}\text { Biomarker of gastrointestinal } \\
\text { protein loss [87] }\end{array}$ & Increased [87] & $\mathrm{AL}$ & $100 \%(8 / 8)[87]$ \\
\hline Total serum protein & $\begin{array}{l}\text { Biomarker of gastrointestinal } \\
\text { protein loss [87] }\end{array}$ & Decreased [87] & $\mathrm{AL}$ & $100 \%(7 / 7)[87]$ \\
\hline
\end{tabular}



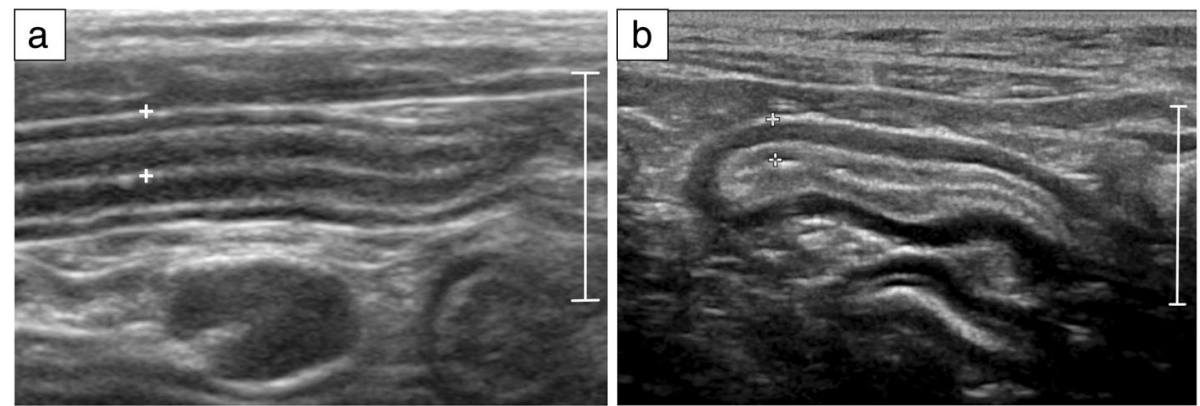

Fig. 1 Ultrasonographic appearance of normal intestine (a) and low-grade alimentary lymphoma (LGAL) (b), longitudinal section. Note the marked thickening of the muscularis propria in the patient with LGAL (b) compared to a cat with a normal jejunal layering (a). The full thickness of both loops (between calipers) is within normal limits: normal jejunum $2.7 \mathrm{~mm}$ and LGAL jejunum $2.5 \mathrm{~mm}$. Scale: $10 \mathrm{~mm}$

Enlarged mesenteric lymph nodes are another common ultrasonographic finding $[8,82,95,101,102]$. In one retrospective study, mesenteric lymphadenomegaly was reported in 6 out of $10 \mathrm{AL}$ cases, and 2 out of 12 IBD cases [77]. Mesenteric lymph node thickness can vary, with the average being 4 to $6 \mathrm{~mm}$ for jejunal lymph nodes and $5 \mathrm{~mm}$ for ileo-caecal lymph nodes $[15,99]$. In AL, changes in lymph node size can be highly variable, ranging from minimal to markedly enlarged, although, in recent studies, moderate enlargement is most likely [2, 59, 77, 95, 96]. Mesenteric lymph node enlargement was reported in 17 LGAL cases in one study, with a mean diameter of $15.9 \mathrm{~mm}$ (range 6.5-30 mm) [59]. In a more recent study, colic lymph nodes in LGAL cats were reported to be 1.6-fold larger in size than those from healthy cats whereas jejunal lymph node hypertrophy was not systematically associated with LGAL [15].

\section{Endoscopy and coeliotomy}

Gastrointestinal endoscopy is an important investigative tool in feline gastroenterology providing the ability to access the stomach, duodenum, distal ileum and colon, as well as allowing direct visualisation of the mucosa $[75,103]$. Experienced endoscopists can often reach the proximal jejunum [103, 104]. It is a minimally invasive and rapid technique allowing macroscopic lesions to be described and multiple intestinal biopsy samples to be collected, albeit exclusively from mucosa or submucosa $[15,20,72,105]$. Mucosal lesions that cannot be characterised by ultrasonographic examination may be identified by endoscopy [75, 106, 107]. Macroscopic differentiation between inflammatory lesions (congestion, oedema, mucosal fibrosis) and LGAL lesions is not possible by endoscopic examination [20, 107]. In addition, the jejunum and the proximal part of the ileum, which are the most frequent locations of LGAL, are often not accessible by endoscopy [105]. Evans et al. suggested exploratory cœliotomy may be preferable to endoscopy [77]. However, in their study involving $10 \mathrm{AL}$ and 12 IBD, duodenal assessment was limited in half the cats and biopsies were performed blindly in 8 of the cats which might have contributed to the poor sensitivity of endoscopic biopsies. By obtaining endoscopic specimens of the jejunum and ileum, laparoscopy may improve the
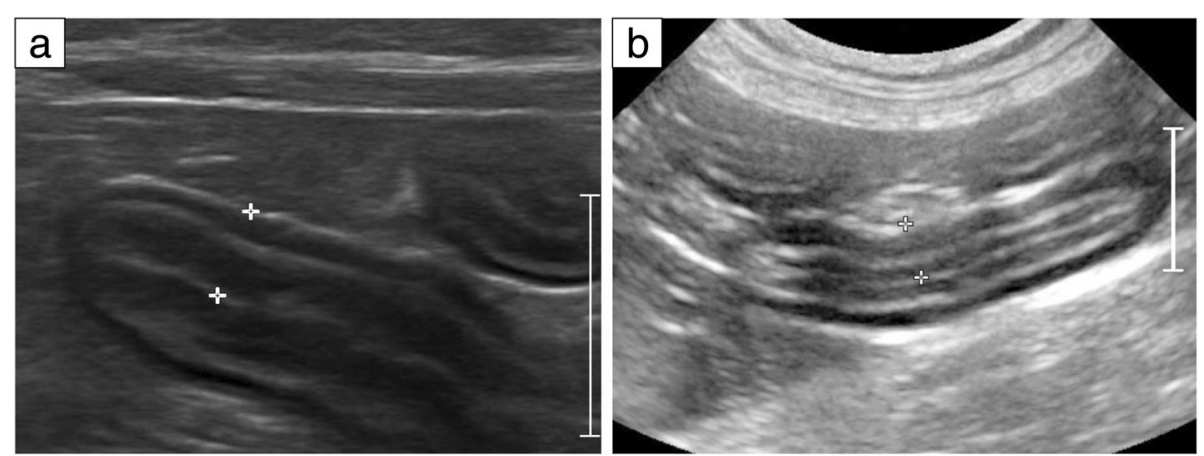

Fig. 2 Ultrasonographic images depicting a diffuse intestinal wall thickening in low-grade alimentary lymphoma (LGAL) (a) and inflammatory bowel disease (IBD) (b). a Cat with advanced LGAL (duodenum): a moderate thickening of the muscularis propria is observed. Full-thickness (between calipers): $3.7 \mathrm{~mm}$. b Cat with IBD, eosinophilic enteritis (small intestine): note the similar ultrasonographic appearance of the intestine compared to LGAL aspect. Full thickness (between calipers): $3.9 \mathrm{~mm}$. Scale: $10 \mathrm{~mm}$ 
Table 3 Comparison of ultrasonographic features observed in low-grade alimentary lymphoma (LGAL) and inflammatory bowel disease (IBD)

\begin{tabular}{|c|c|c|}
\hline $\begin{array}{l}\text { Ultrasonographic } \\
\text { parameter }\end{array}$ & LGAL & $\mathrm{IBD}$ \\
\hline $\begin{array}{l}\text { Gastrointestinal } \\
\text { wall thickness }\end{array}$ & $\begin{array}{l}\text { Muscularis propria } \\
\text { frequently thickened } \\
{[8,15,59,82,95,101]}\end{array}$ & $\begin{array}{l}\text { Muscularis propria } \\
\text { frequently thickened } \\
\text { in eosinophilic enteritis } \\
\text { (EE), possibly increased } \\
\text { in lymphoplasmacytic } \\
\text { enteritis (LPE) } \\
{[15,78,82,84,95,101]}\end{array}$ \\
\hline $\begin{array}{l}\text { Size of } \\
\text { mesenteric } \\
\text { lymph nodes }\end{array}$ & $\begin{array}{l}\text { Lymphadenomegaly } \\
(>5 \mathrm{~mm}) \text { frequent } \\
\text { but not systematic } \\
{[8,82,95,101,102]}\end{array}$ & $\begin{array}{l}\text { Lymphadenomegaly } \\
\text { frequent but not } \\
\text { systematic }[78,82,95]\end{array}$ \\
\hline $\begin{array}{l}\text { Gastrointestinal } \\
\text { intramural } \\
\text { masses }\end{array}$ & Rare but possible [75] & Rare but possible [75] \\
\hline $\begin{array}{l}\text { Stratification } \\
\text { and architecture }\end{array}$ & $\begin{array}{l}\text { Normal }[8,59] \\
\text { to modified }[61,82,101]\end{array}$ & $\begin{array}{l}\text { Normal to modified } \\
{[82,95]}\end{array}$ \\
\hline Motility & Normal to reduced [95] & Normal to reduced [95] \\
\hline Intussusception & Rare but possible $[2,75]$ & $\begin{array}{l}\text { Very rare but possible } \\
{[2,75]}\end{array}$ \\
\hline Liver appearance & $\begin{array}{l}\text { Hypo- or } \\
\text { hyperechogenicity } \\
\text { possible, lobular } \\
\text { pattern if } \\
\text { liver involved [2] }\end{array}$ & Non specific [2] \\
\hline Pancreas & NA & $\begin{array}{l}\text { Changes suggestive } \\
\text { of pancreatitis } \\
\text { (pancreatic } \\
\text { hypoechogenicity, } \\
\text { peripancreatic } \\
\text { hyperechoic fat) } \\
{[78,173]}\end{array}$ \\
\hline
\end{tabular}

NA not available

diagnostic sensitivity and may therefore be a minimally invasive alternative to exploratory coliotomy [77].

Although exploratory cœliotomy is more invasive than endoscopy, all segments can be inspected, full-thickness biopsies (mucosa, submucosa, muscularis and serosa) can be taken from various sites (stomach, duodenum, jejunum and ileum) $[3,4,11,15,59,75]$, and biopsies of other organs (e.g. peripheral lymph nodes, liver, and pancreas) if indicated [99]. The technique is generally safe with post-operative complications being uncommon [108]. Indeed, there was no clinical evidence of postoperative leakage from the biopsy sites and a low incidence of post-operative complications in published reports involving $70 \mathrm{AL}$ cases where full-thickness gastrointestinal biopsies were taken $[75,76]$. Unfortunately, regardless of method used for biopsy sampling, diagnosis remains challenging because of the frequent lack of gross changes in cases of LGAL. Multiple systematic biopsies of all the digestive areas are therefore recommended $[14,61,79,107]$.

\section{Cytology and histology}

Both cytological and histological assessment can be used to aid in the diagnosis of AL in cats. Whilst cytology samples can be easier to collect, results may be unreliable, particularly for LGAL, where the rate of false-negatives for mesenteric lymph nodes can reach $50 \%[59,60,75,107,109-111]$. Few intra-abdominal lymph node cytology results are positive for LGAL, possibly because the neoplastic lymphocyte population mainly comprises small lymphocytes, which would not be considered to be unusual in a lymph node [60]. Conversely, aspiration cytology of focal intestinal wall masses or enlarged mesenteric lymph nodes are considered adequate to diagnose HGAL or LGLL $[82,107]$.

Histological examination of the small intestine is important in establishing a diagnosis of $\mathrm{AL}[1,28,97,101,109$, 112 ], and it is advisable to define clinical features according to the guidelines of the World Small Animal Veterinary Association Gastrointestinal Standardization Group [104, 113]. LGAL lesions are characterised by an infiltrate of neoplastic lymphocytes of small-to-intermediate size and involving the epithelium and lamina propria of the villus (Fig. 3); infiltration of the submucosa and muscularis is also frequent $[6,58,60,75]$. Since the MALT includes the largest population of lymphoid and accessory immune cells in the gastrointestinal tract, it is the primary site of neoplastic proliferation $[6,114]$. Differentiation between inflammatory and neoplastic infiltrates is often challenging because the histological features of LGAL and IBD (especially lymphoplasmacytic enteritis) can be similar (Fig. 3) [58, 82]. However, amongst the criteria to distinguish LGAL from IBD, epitheliotropism, defined as the characteristic homing of neoplastic T-cells to the mucosal epithelium [60], is arguably most important, and in particular the presence of intraepithelial nests and plaques [6, 19, 60, 61, 79]. An intraepithelial nest is defined as 5 or more small T-lymphocytes clustered within the villous epithelium, and an intraepithelial plaque as 5 or more adjacent epithelial cells obscured by infiltrates of small T-lymphocytes [61, 85]. Mild cases may be limited to purely intra-mucosal infiltration of small T-cells into the epithelium layer [60]. Two studies found that the majority of the intraepithelial lymphocytes in healthy and specific pathogen-free cats were $\mathrm{CD}^{+}[114,115]$. Whilst epitheliotropism is suggestive of LGAL rather than IBD, its absence cannot be used to exclude the condition because it is not observed in all digestive T-cell lymphomas [61].

Therefore, intraepithelial lymphocytes are an important cell population to study during histological assessment of feline gastrointestinal biopsies, and are usually of T-cell phenotype $[6,60]$. In healthy cats, there are many more intraepithelial lymphocytes in the villous epithelium than in the crypt epithelium in all regions of the small intestine, and this is also for cats with IBD, AL, 


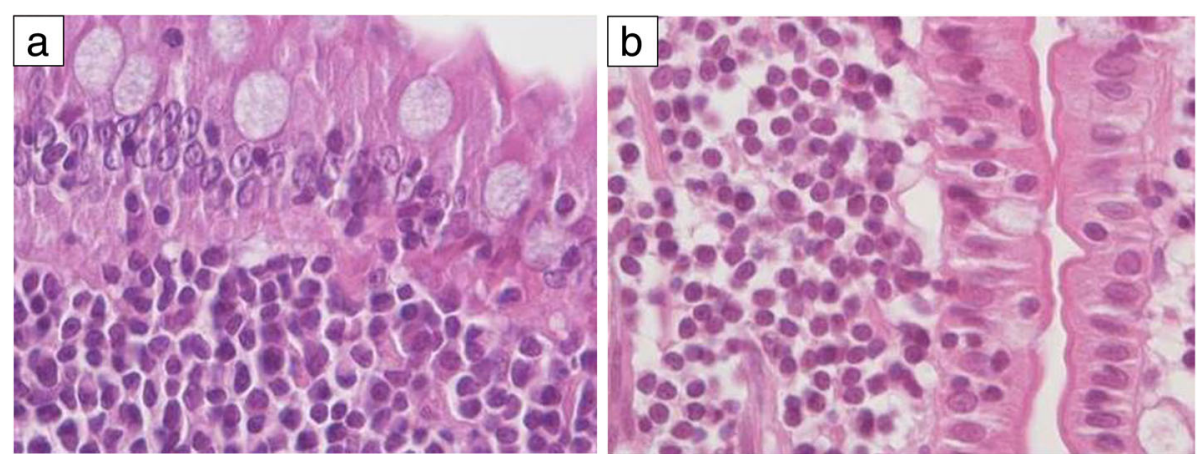

Fig. 3 Histological features of low-grade alimentary lymphoma (LGAL) and plasmacytic enteritis (haematoxylin-eosin-staining, 400X). a LGAL: monomorphic dense infiltrate of small lymphocytic cells with discrete nuclear atypia; some plasma cells are present. $\mathbf{b}$ Plasmacytic enteritis: less compact infiltrate of small lymphocytes with dense nucleus; more plasma cells are present

and epitheliotropic intestinal malignant lymphoma (EIL) $[60,115]$. However, there are usually markedly more intraepithelial lymphocytes in cats with EIL than either healthy cats or cats with IBD [60]. Further, the common occurrence of epitheliotropism in small intestinal T-cell lymphoma has been described $[6,57,60]$, with one study demonstrating that $62 \%$ of mucosal T-cell lymphoma of small-cell type had characteristics of EIL. Epitheliotropism is also an important feature of HGAL, occurring in 58\% of transmural T-cell lymphoma and in some T-cell LGLL of the small intestine $[6,114,116]$.

Inter-observer variability can occur and histology must be correlated with clinical status and outcome [117, 118]. Moreover, a discrepancy between the perceived lower number of intraepithelial lymphocytes based on HE stains and the greater number of intraepithelial lymphocytes based on CD3 stain has been noted, possibly because of the difficulty in differentiating them from enterocytes in HE-stained sections $[60,115]$. In addition to the described changes in lymphocyte populations, concurrent histological abnormalities in neoplastic regions include lymphoid microabscesses in the mucosal epithelium, villous blunting and fusion, increased plasma cell infiltrate within the lamina propria and eosinophil infiltrate into the lamina propria [60].

\section{Immunohistochemistry}

Immunohistochemistry has become an increasingly important molecular technique to improve the diagnosis of AL, especially to aid in the differentiation of LGAL and IBD $[10,15,62,77,103,106,119]$. Since it can often be performed on formalin-fixed and paraffin-embedded (FFPE) biopsies, it must be readily performed as a complementary technique to standard histological examination. With IHC, specific monoclonal antibodies are applied that recognise antigenic determinants (epitopes), thereby enabling microscopic detection of differentiation and proliferation biomarkers $[10,62,111]$. The most commonly-used antibodies include anti-CD3 to detect T-lymphocytes $[6,10,39,60-62,79,120]$, coupled with anti-CD79a, anti-CD20 and anti-BLA36 to detect B-lymphocytes [39, 60-62, 72, 103], MAC387 highlights macrophages $[10,62]$, and anti-CD57 is used to detect natural killer (NK) cells [6]. Moreover, the percentage of proliferating cells can also be determined immunohistochemically by detecting Ki67 expression [10]. Ki67 is expressed in the nucleus during all phases of the cell division cycle, with its concentration increasing during the cell cycle, becoming maximal expression in M-phase and then totally disappearing after mitosis [10, 121, 122]. However, whilst useful, the authors are not aware of any threshold value that reliably discriminates either between the different feline AL subtypes, or IBD [10]. Other specific feline antibodies (anti-CD4, anti-CD8 $\alpha$, anti-CD8 $\beta$ ) can be used to detect additional epitopes and define the immunophenotype of lymphomas, but their routine clinical application is limited by the fact that formalin-fixed samples cannot be used as frozen sections are required [10].

LGAL is of T-cell phenotype in $90 \%$ of the cases, staining positively with anti-CD3 antibody (Fig. 4), with a B-cell phenotype observed in the remaining $10 \%$ of cases $[6,8,10,11,58,63,75,97]$. However, there is increasing evidence that some human and canine T-cell lymphomas co-express the B-cell marker CD20 [123125]. In a three-case series reported by Nolan and Kiupel (2018), the majority of neoplastic $\mathrm{CD}^{+}$lymphocytes expressed CD20 but not Pax5. In all cases, PARR testing demonstrated clonal rearrangement of the T-cell receptor gamma gene, suggesting a diagnosis of $\mathrm{CD}^{+}, \mathrm{CD}^{2} \mathrm{O}^{+}$ enteropathy-associated T-cell lymphoma, large cell type [80]. This explains why the PARR is most suited to detecting clonally expanded lymphocyte populations, rather than determining phenotype [85].

Moreover, human peripheral T-cell lymphoma may exhibit aberrant expression of CD20 [123], and a subset of 

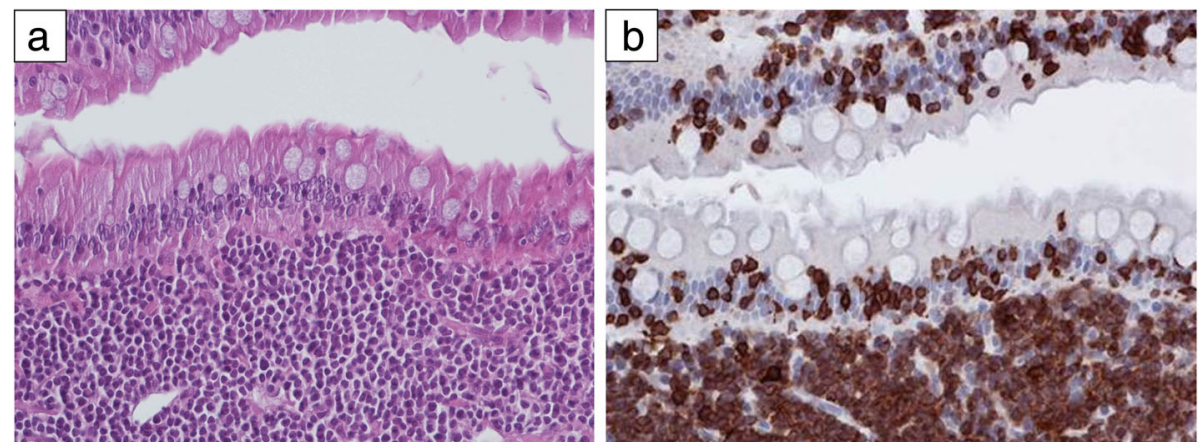

Fig. 4 Histological (a) (haematoxylin-eosin-staining, 200X) and immunohistochemical (b) (anti-CD3, immunoperoxydase, 200X) features of lowgrade alimentary lymphoma (LGAL) showing dense infiltration of the lamina propria composed of a mixture of small $\mathrm{CD}^{+} \mathrm{T}$ lymphocytes and plasma cells, with epitheliotropism (small intestine biopsies)

T-lymphocytes with low-expression of CD20 (known as $\mathrm{CD} 20^{\mathrm{dim}}$ T-lymphocytes) has been detected in normal peripheral human blood [126]. It is not currently known whether CD20 expression in canine lymphoma reflects aberrant expression or whether the neoplastic lymphocytes originated from a subpopulation of normal CD20 ${ }^{\mathrm{dim}}$ T-cells. Finally, in a recent study involving 40 T-cell AL, 5 B-cell AL and 8 IBD, T-cell lymphomas in particular were characterised by a high percentage of Bcl-2 (B-cell lymphoma gene 2) labelled cells, whilst B-cell lymphomas varied more widely in the number of positively-labelled cells [19]. Further studies are required to clarify the exact phenotypes of LGAL, although this has been hampered by the limited number of antibodies available for IHC studies.

\section{Clonality testing}

In conjunction with other diagnostic techniques, clonality analyses have been increasingly used in veterinary pathology to differentiate reactive and neoplastic lymphoid proliferations, for example differentiating IBD from LGAL $[6,112,127]$. This diagnostic tool was first reported for feline intestinal T-cell lymphoma by Moore et al. in 2005 [57], with the most commonly reported approach being PARR. This technique is based on PCR targeting of the CDR3 region of T-cell receptor gamma (TCR $\gamma$ ) for T-cells and immunoglobulin heavy chain genes (IGH) for B-cells [57, 58, 85, 95, 111, 127-129], and can detect clonally expanded lymphocyte populations. However, PARR cannot determine lymphocyte phenotype and, therefore, it complements rather than replaces the use of immunohistochemistry. This is because neoplastic lymphocytes may have clonal rearrangement of either or both the T- or B-cell antigen receptor genes, regardless of phenotype [57, 61, 85, 130]. For example, cases of mucosal T-cell lymphoma of small cell type may show clonal rearrangement of the IGH gene. This is termed cross-lineage rearrangement and can be an effect of malignant transformation but causes remain to be elucidated $[61,85,131,132]$. Cross-lineage rearrangement has previously been reported in both human and canine T-cell malignancies [133, 134].

More than $90 \%$ of LGAL exhibit a clonal or oligoclonal $\mathrm{TCR} \gamma$ gene rearrangement, whereas IBD usually displays a polyclonal pattern $[6,57]$. Moreover, the diagnostic sensitivity and specificity of PCR-based clonality assays for routine diagnosis of feline $\mathrm{TCR} \gamma$ gene rearrangement are currently close to $90 \%[6,57,128,135]$. As a result, Sabattini et al. recommended the assessment of clonality in duodenal endoscopic biopsies to increase the detection sensitivity to distinguish between LGAL and IBD [112]. Taken together, these data suggest that clonality testing should be integrated in the routine diagnosis work-up of LGAL. Initially developed on frozen samples, molecular clonality testing can now be performed on formalin-fixed and paraffin-embedded (FFPE)-derived samples [136], making this assay more easily accessible. The average sensitivity for diagnosis of feline AL was highest (0.83), intermediate (0.78), and lowest (0.72) for using histology and IHC and clonality, histology and IHC, and histology alone, respectively $[61,107]$.

Even where there is agreement between histological findings and clonality analysis, clinical, morphological, and immunophenotypic data should ideally be integrated with clonality analysis in order to reduce the chances of a misdiagnosis $[6,19,61,82,127]$. Cross-lineage rearrangement of the IGH gene was detected in at least $9 \%$ of cases diagnosed as T-cell AL $[85,129]$. Moreover, a polyclonal rearrangement of the TCR $\gamma$ gene can also be observed. Reasons for this pattern include the presence of inflammatory T-cell infiltrates within the evaluated tissues which then mask the clonal T-cell population, or the exclusive amplification of the TCR $\gamma$ gene of resident or inflammatory $\mathrm{T}$-cell populations of the intestine [57, 85]. Conversely, detection of a clonal lymphocyte population is not always indicative of 
Table 4 Comparison of aetiology, epidemiology, and clinical features in cats with low-grade alimentary lymphoma (LGAL) and inflammatory bowel diseases (IBD)

\begin{tabular}{|c|c|c|}
\hline & LGAL & $\mathrm{IBD}$ \\
\hline Aetiology & Currently unknown & $\begin{array}{l}\text { Currently unknown, multifactorial } \\
\text { disease, though many factors implicated } \\
\text { including genetic factors and } \\
\text { enteric bacteria or protozoa }[3,11,52,63]\end{array}$ \\
\hline Age & Mainly older cats [4] & Any age $[63,78,79,82]$ \\
\hline Breed & No breed predisposition [59] & $\begin{array}{l}\text { Domestic shorthair and longhair, } \\
\text { Persian, Siamese predisposed }[63,78,79,87]\end{array}$ \\
\hline Gastrointestinal locations & $\begin{array}{l}\text { Any but jejunum and ileum } \\
\text { most common (90\%) }[58,59,119]\end{array}$ & $\begin{array}{l}\text { Any but duodenum and } \\
\text { ileum most common }(70-90 \%)[58,59,119]\end{array}$ \\
\hline Clinical signs & $\begin{array}{l}\text { Weight loss, vomiting, } \\
\text { anorexia, diarrhea, lethargy }[8,63,79]\end{array}$ & $\begin{array}{l}\text { Weight loss, vomiting, anorexia, } \\
\text { diarrhea, lethargy }[8,63,79]\end{array}$ \\
\hline \multicolumn{3}{|l|}{ Biomarkers } \\
\hline Albumin & Decreased (49\%) & Decreased (77\%) [87] \\
\hline Total proteins & NA & Increased (18\%) [78] \\
\hline Cobalamin & $\begin{array}{l}\text { Decreased }(50-80 \%) \\
{[2,8,11,75,82,83,87,90,94]}\end{array}$ & Decreased $(18-47 \%)[78,82,87]$ \\
\hline Folate & Increased (37\%) [72] & Increased (22\%) [87] \\
\hline LDH & Increased (47\%) [172] & Increased (26\%) [172] \\
\hline ALP and ALT & NA & Increased (23\%) [78] \\
\hline fPLI & NA & Increased (18\%) [78] \\
\hline Phosphate & NA & Decreased (47\%) [78] \\
\hline Ultrasonography & $\begin{array}{l}\text { Muscularis propria frequently } \\
\text { thickened [8, 15, 59, 95, 101]; } \\
\text { mesenteric (i.e. jejunal) } \\
\text { lymphadenomegaly frequent } \\
\text { [95]; gastrointestinal } \\
\text { intramural masses rare [75]; } \\
\text { stratification, architecture and } \\
\text { motility normal to modified [95] }\end{array}$ & $\begin{array}{l}\text { Muscularis propria frequently } \\
\text { thickened in eosinophilic enteritis } \\
\text { (EE), and occasionally in lymphoplasmacytic } \\
\text { enteritis (LPE) }[15,78,84,95,101] \text {; } \\
\text { mesenteric lymphadenomegaly } \\
\text { frequent }[78,95] \text {; gastrointestinal } \\
\text { intramural masses rare [75]; } \\
\text { stratification architecture, } \\
\text { and motility normal to modified [95] }\end{array}$ \\
\hline $\begin{array}{l}\text { Histological features } \\
\text { and immunohistochemistry }\end{array}$ & $\begin{array}{l}\text { Diffuse infiltration } \\
\text { by monomorphic } \\
\text { neoplastic T-cells }[6,8]\end{array}$ & $\begin{array}{l}\text { Polymorphic inflammatory infiltrate } \\
\text { of lymphocytes, plasma cells (LPE), } \\
\text { neutrophils, eosinophils } \\
\text { (EE), and macrophages }[75,84,174]\end{array}$ \\
\hline Clonality test & $\begin{array}{l}\text { Clonal population of } \\
\text { lymphocytes }[10,15,62,95]\end{array}$ & $\begin{array}{l}\text { Polyclonal population } \\
\text { of lymphocytes }[10,15,95,174]\end{array}$ \\
\hline
\end{tabular}

NA not available

neoplasia, since this can sometimes be seen as a response to pathogens and concurrent malignancies [61, 85]. In the study of Kiupel et al., involving $47 \mathrm{AL}$ and 16 IBD, one case had clonal population of B-cells and a final diagnosis of IBD was made, when histomorphology and immunophenotyping results were taken into consideration. Amongst ten cats with an oligoclonal population of T-cells, one case was diagnosed as IBD [61]. Moreover, high percentage of clonality has been associated with marked inflammatory process in humans [137].

That said, whilst clonality testing can provide additional information on a particular case, the use in diagnosis has not yet been critically reviewed and properly validated. Therefore, for now, clinicians should be cautious about reclassifying cats previously diagnosed with
IBD to lymphoma on the basis of PARR, and a combination of conventional histopathology and immunohistochemistry (IHC) remains the current gold-standard test.

\section{Staging}

To our knowledge, the staging criteria classically defined for other types of lymphoma cannot be reliably used to classify LGAL $[3,5,20,38]$.

\section{Distinguishing low-grade alimentary lymphoma from inflammatory bowel disease}

As discussed above, a major challenge of the clinician is to distinguish LGAL from IBD given that their clinical presentations overlap. Table 4 provides a summary of 
Table 5 Description of chemotherapy protocols based on Chlorambucil (PO) and Prednisolone (PO) administration in low-grade alimentary lymphoma (LGAL) [20, 59, 72, 97]

\begin{tabular}{|c|c|c|c|c|}
\hline Study & Stein et al. [97] & Lingard et al. [59] & Kiselow et al. [72] & Fondacaro et al. [20] \\
\hline Number of cases & 28 & 12 & 41 & 29 \\
\hline Prednisolone & $1-2 \mathrm{mg} / \mathrm{kg} \mathrm{PO} \mathrm{q} 24 \mathrm{~h}^{\mathrm{b}}$ & $\begin{array}{l}3 \mathrm{mg} / \mathrm{kg} \mathrm{PO} \mathrm{q} 24 \mathrm{~h} \text {, } \\
\text { tapering } \\
\text { to } 1-2 \mathrm{mg} / \mathrm{kg} \text { once } \\
\text { in remission }\end{array}$ & $5 \mathrm{mg} / \mathrm{cat} \mathrm{PO}$ q12-24 h & $10 \mathrm{mg} / \mathrm{cat} \mathrm{PO} / \mathrm{cat} / \mathrm{da}$ \\
\hline Chlorambucil & $20 \mathrm{mg} / \mathrm{m}^{2} \mathrm{PO} \mathrm{q} 2 \mathrm{wk}^{\mathrm{c}}$ & $\begin{array}{l}15 \mathrm{mg} / \mathrm{m}^{2} \text { PO q24h } \\
\text { for } 4 \mathrm{~d} \text { q3wk }\end{array}$ & $2 \mathrm{mg} / \mathrm{cat} \mathrm{PO} \mathrm{q} 48 \mathrm{~h}$ & $\begin{array}{l}15 \mathrm{mg} / \mathrm{m}^{2} \text { PO q24h } \\
\text { for } 4 \mathrm{~d} \mathrm{q}^{3} \mathrm{wk}^{\mathrm{d}}\end{array}$ \\
\hline Number responding & $27(96 \%)$ & NA & 37 (95\%) & NA \\
\hline Complete remission rate & NA & NA & $22(56 \%)$ & $20(69 \%)$ \\
\hline Median remission time ${ }^{a}$ & 786 days & 505 days & 897 days & 615 days \\
\hline Median survival time & NA & 513 days & 704 days & 510 days \\
\hline
\end{tabular}

NA not available

${ }^{\mathrm{a}}$ Remission time in days for cats displaying a complete response; ${ }^{\mathrm{b}}$ Two cats received dexamethasone, initially at immunosuppressive dosages and then at dosages that were gradually tapered over the course of 3 weeks; ${ }^{c}$ Because of client preference, two cats were switched to $20 \mathrm{mg} / \mathrm{m}^{2}$ chlorambucil orally q3wk; ${ }^{\mathrm{d}} \mathrm{Twelve}$ of the 20 cats that achieved CR received cyclophosphamide $225 \mathrm{mg} / \mathrm{m}^{2}$ PO q3wk, once they were out of remission

the two conditions comparing aetiology, signalment, clinical signs, and diagnosis.

\section{Treatment}

\section{Chemotherapy}

Systemic chemotherapy is generally considered to be the most effective treatment for AL [2, 39], although protocols have not been frequently described [3]. Compared with other forms of lymphoma, less intensive chemotherapy protocols have been suggested [20], with the most common protocols involving oral administration of both glucocorticoids (prednisolone or dexamethasone) and chlorambucil (Table 5) [20, 59, 72, 97]. The optimal duration of chemotherapy has not been determined and, because these drugs are well tolerated, treatment is rarely discontinued. In one study involving 56 cases of feline small cell lymphomas (37 AL), all cats were treated with glucocorticoid and chlorambucil with discontinuation of treatment recommended at one year if complete clinical response was documented. Subsequent reintroduction as rescue chemotherapy appears to be just as effective as continued administration in cats and median overall survival times for cats with AL was 1148 days [96].

\section{Rescue protocol}

Other chemotherapy protocols can be used if relapse is experienced, with examples including: cyclophosphamide and prednisolone; cyclophosphamide, vincristine and prednisolone (COP protocol) +/- L-asparaginase and doxorubicin (VELCAP-C); lomustine PO with or without corticosteroid $[2,4,7,39,82]$. In the study of Stein et al., involving 28 cats diagnosed with LGAL and treated with a combination of chlorambucil and glucocorticoids, seven of the nine cats with relapsed disease were treated with a rescue protocol of cyclophosphamide
(PO $200-250 \mathrm{mg} / \mathrm{m}^{2}$ given on days 1 and $3 \mathrm{q} 2 \mathrm{wk}$ ) and prednisolone (5 $\mathrm{mg} \mathrm{q} 48 \mathrm{~h}$ ). The response rate was $100 \%$ based on resolution of clinical signs and normal abdominal palpation. Three cats died of unrelated diseases, three cats were lost to follow-up, and the final cat relapsed 241 days after starting the rescue protocol [97]. However, to the authors' knowledge, there are no studies comparing the outcome of cats with LGAL treated by other recue protocols, mainly because studies include all subtypes of AL. Interestingly, one cat in the study of Lingard et al. did not respond to a multi-agent protocol, but entered long-term remission with oral administration of prednisolone and chlorambucil, suggesting that LGAL may be sensitive to alkylating agents such as Chlorambucil [59].

\section{Surgical resection}

Given that LGAL lesions are usually diffuse, surgical resection is rarely indicated as a means of managing the disease. In rare cases where an obstructive mass lesion is present, partial resection could be considered as part of the treatment $[107,138]$. The main disadvantage of surgical resection is the risk of post-operative complications $[76,139]$, which can include dehiscence, typically occurring between 2 and 5 days after surgery [75]. Nevertheless, in one study involving 20 cases of intermediate -/high-grade AL where surgical resection of disease was performed prior to CHOP-based chemotherapy, no post-operative surgical complication occurred [138]. Cats with AL do not appear to be at high risk of post-operative complications after full-thickness gastrointestinal surgery $[138,139]$.

\section{Adjuvant therapy}

In addition to chemotherapy, a highly digestible diet is typically recommended, with appetite stimulants (most 
Table 6 Pathological features of human digestive T-cell lymphoma $[25,153,164,165,175,176]$

\begin{tabular}{|c|c|c|c|c|}
\hline & Clinical features & Histology & Immunophenotype & Outcome \\
\hline Indolent digestive T-cell lymphoproliferative disease & $\begin{array}{l}\text { Diarrhoea, } \\
\text { abdominal pain }\end{array}$ & $\begin{array}{l}\text { - Crypt hyperplasia, variable } \\
\text { degrees of villous atrophy } \\
\text { - Non-destructive superficial } \\
\text { infiltrate of small uniform } \\
\text { T-cells mostly lamina } \\
\text { propria-based } \\
\text { - Infiltration into submucosa } \\
\text { observed in some cases } \\
\text { - No evident major } \\
\text { epitheliotropism }\end{array}$ & $\begin{array}{l}\text { CD3+, CD8+ or CD4+, } \\
\text { CD2+, CD5+/-, CD7+/-, } \\
\text { CD30-, CD56-, TCRaß+ }\end{array}$ & $\begin{array}{l}\text { Indolent chronic } \\
\text { relapsing course }\end{array}$ \\
\hline Enteropathy associated T-cell lymphoma (EATL) & $\begin{array}{l}\text { Overt or silent } \\
\text { gluten-sensitive } \\
\text { enteropathy }\end{array}$ & $\begin{array}{l}\text { - Crypt hyperplasia, } \\
\text { villous atrophy } \\
\text { - Pleomorphic medium- to } \\
\text { large-sized neoplastic } \\
\text { lymphocytes with } \\
\text { transmural infiltration } \\
\text { - Presence of other mixed } \\
\text { inflammatory cells such } \\
\text { as histiocytes and eosinophils } \\
\text { - Intraepithelial lymphocytosis } \\
\text { present in non-tumoral } \\
\text { mucosa and in epithelium } \\
\text { distant from the main mass }\end{array}$ & $\begin{array}{l}\text { CD3+, CD5-, CD8-/+, } \\
\text { CD56-, CD103+, often } \\
\text { CD30+, cytotoxic } \\
\text { phenotype +/-, } \\
\text { TCR a + (usually) }\end{array}$ & Aggressive \\
\hline Monomorphic epitheliotropic T-cell lymphoma & $\begin{array}{l}\text { Occurs without } \\
\text { a history of } \\
\text { coeliac disease }\end{array}$ & $\begin{array}{l}\text { - No crypt hyperplasia, } \\
\text { possible villous atrophy } \\
\text { - Monomorphic infiltrate } \\
\text { with epitheliotropism } \\
\text { - Transmural infiltration } \\
\text { - No associated } \\
\text { inflammatory background }\end{array}$ & $\begin{array}{l}\text { CD3+, CD5-, CD4-, } \\
\text { CD8+, CD56+, cytotoxic } \\
\text { phenotype, CD30-, } \\
\text { TCR } \gamma \delta+\text { (usually) }\end{array}$ & Aggressive \\
\hline
\end{tabular}

commonly mirtazapine $3.75 \mathrm{mg} /$ cat PO, every 3 days) used in cats with partial or complete anorexia [75, 107]. A recent paper described the use of growth hormone secretagogues, such as capromorelin, for appetite stimulation in cats [140]. Capromorelin was already shown to increase food intake or weight gain in dogs and humans $[141,142]$. Treatment with capromorelin at $6 \mathrm{mg} / \mathrm{kg}$ once daily for 91 days in 8 healthy laboratory cats resulted in increased body weight and a greater mean food consumption compared to the 4 placebo-treated cats. The optimal clinical dose of capromorelin in cats has yet to be confirmed, although no serious adverse events were observed in the recent study [140].

Cats with concurrent hypocobalaminaemia are usually treated with supplemental cobalamin (e.g. $250 \mu \mathrm{g} /$ cat SC once weekly for at least 6 weeks), although there is no clear consensus on doses and duration [72, 82, 86, 87]. The clinical benefits of prebiotics, probiotics and gluten-free diet as adjuvant therapies in LGAL have not yet been proved and need to be investigated in randomised studies [107].

\section{Prognosis}

In contrast to HGAL and LGLL, prognosis for LGAL is good with a high remission rate when the treatment is carried out over several months or years [13, 14, 59, 75, 82]. Most causes of death include relapse, comorbidities, or euthanasia in accordance with the owner's request $[20,59,107]$. Initial response to chemotherapy seems to be the most significant prognostic indicator $[5,20,40$, 143-145], with the presence of lethargy, vomiting and anorexia at initial diagnosis also considered to be negative prognosis factors [59]. However, no association has been observed between the response to LGAL treatment and a variety of other factors including: age, weight, sex, type and duration of clinical signs, presence of extra intestinal lesions, and decreased concentrations of folate, cobalamin and plasma total protein [38, 72, 75, 120]. It remains unclear as to whether, in the long-term, LGAL can progress to more aggressive forms of AL.

\section{Discussion \\ A model for human indolent T-cell lymphoproliferative disorders of the gastrointestinal tract?}

Within the "One-Health" concept, the domestic cat is considered to be a good model for comparative biomedical research. Indeed, naturally-occurring feline cancers offer opportunities for comparative and translational advances that could be of mutual benefit for both human and veterinary oncology [146-148]. Therefore, as well as improving diagnostic tools for feline LGAL, identifying aetiological factors in cats may ultimately be beneficial to human patients with indolent digestive lymphoma. 
Table 7 Comparison of feline low-grade alimentary lymphoma (LGAL) and human indolent digestive T-cell lymphoproliferative disease (LPD)

\begin{tabular}{|c|c|c|}
\hline Data & Feline LGAL & $\begin{array}{l}\text { Human indolent digestive T-cell } \\
\text { LPD }\end{array}$ \\
\hline Epidemiology & $\begin{array}{l}\text { Frequent, increasing } \\
\text { prevalence over } \\
\text { the last decade }\end{array}$ & Very rare \\
\hline Clinical signs & $\begin{array}{l}\text { Non-specific weight } \\
\text { loss, vomiting, } \\
\text { anorexia, diarrhoea }\end{array}$ & $\begin{array}{l}\text { Non-specific weight I } \\
\text { oss, diarrhoea, abdominal } \\
\text { pain, digestive bleeding, } \\
\text { malnutrition }\end{array}$ \\
\hline $\begin{array}{l}\text { Gastrointestinal } \\
\text { localisation }\end{array}$ & $\begin{array}{l}\text { Multiple lesions } \\
\text { affecting all the } \\
\text { gastrointestinal } \\
\text { tract; small intestine } \\
\text { as main involvement }\end{array}$ & $\begin{array}{l}\text { Multiple lesions affecting } \\
\text { all the gastrointestinal } \\
\text { tract; small intestine } \\
\text { as main involvement }\end{array}$ \\
\hline Histology & $\begin{array}{l}\text { Monomorphic } \\
\text { population of small- } \\
\text { to intermediate-sized } \\
\text { T-lymphocytes; } \\
\text { infiltration of neoplastic } \\
\text { T-cells in villi and lamina } \\
\text { propria; moderate } \\
\text { villous atrophy; } \\
\text { crypt hyperplasia }\end{array}$ & $\begin{array}{l}\text { Monomorphic population } \\
\text { of small- to intermediate-sized } \\
\text { T-lymphocytes } \\
\text { Infiltration of neoplastic } \\
\text { T-cells in villi and lamina } \\
\text { propria; villous atrophy } \\
\text { (often severe); } \\
\text { crypt hyperplasia; } \\
\text { erythema of the } \\
\text { mucosa; ulcers; } \\
\text { mucosal nodularity }\end{array}$ \\
\hline Immunophenotyping & CD3+ & $\begin{array}{l}\text { CD3+ CD4+ (frequent) } \\
\text { or CD8+ or CD4-/CD8- (rare) }\end{array}$ \\
\hline Clonality pattern & $\begin{array}{l}\text { Clonal or oligoclonal } \\
\text { TCRy rearrangement }\end{array}$ & $\begin{array}{l}\text { Clonal or oligoclonal } \\
\text { TCRy rearrangement }\end{array}$ \\
\hline $\begin{array}{l}\text { Main differential } \\
\text { diagnosis }\end{array}$ & $\begin{array}{l}\text { Inflammatory bowel } \\
\text { disease }\end{array}$ & $\begin{array}{l}\text { Refractory coeliac } \\
\text { disease, autoimmune } \\
\text { enteropathy }\end{array}$ \\
\hline \multirow[t]{2}{*}{ Outcome } & Indolent evolution & Indolent evolution \\
\hline & $\begin{array}{l}\text { Median survival time of } \\
2 \text { years }\end{array}$ & $\begin{array}{l}\text { Persistent disease } \\
\text { at a median } \\
\text { follow up of } 5 \text { years }\end{array}$ \\
\hline \multirow[t]{2}{*}{ Treatment } & No gold standard & No gold standard \\
\hline & $\begin{array}{l}\text { Chlorambucil and } \\
\text { steroids most common }\end{array}$ & $\begin{array}{l}\text { "Watch and wait" } \\
\text { strategy, immunosuppressive } \\
\text { agents, chemotherapy } \\
\text { (CHOP regimen), } \\
\text { anti CD52 monoclonal antibody }\end{array}$ \\
\hline
\end{tabular}

\section{Human indolent T-cell lymphoproliferative diseases of the gastrointestinal tract}

Human primary gastrointestinal lymphomas are very rare, accounting for less than $5 \%$ of all non-Hodgkin lymphomas (NHL) yet representing the largest group of primary extranodal NHL, with approximately $25 \%$ of cases occurring in the gastrointestinal tract [19, 149]. They are predominantly located in the stomach (50$60 \%)$, whereas intestinal lymphomas are less common and affect the small and large bowel in $20-30 \%$ and $10-$ $20 \%$ of cases, respectively [150-152]. Amongst primary intestinal $\mathrm{T}$ and NK-cell lymphoma, indolent intestinal T-cell lymphomas are newly described forms of low-grade, diffusely infiltrating T-cell lymphomas.

Indolent T-cell lymphoproliferative diseases (LPD) of the gastrointestinal tract have been described as clonal T-cell proliferations, with an indolent clinical course after long-term monitoring [153]. These diseases are very rare and have only been reported as sporadic cases or in small case series [154-161]. Patients commonly present with chronic diarrhoea, weight loss, malnutrition, abdominal pain or rectal bleeding. In some cases, autoimmune diseases may develop, for example coeliac disease or autoimmune enteropathy [154-156, 162]. Macroscopic findings include villous atrophy, mucosal erythema, erosions or small ulcerations and, occasionally, small polyps without mass lesions [149]. Patients usually have multiple lesions along the gastrointestinal tract, most commonly in the small intestine and colon [149]. On histological examination, the lamina propria is densely infiltrated with a monomorphic population of small lymphoid cells. Severe intestinal villous atrophy, caused by the lamina propria infiltration, is commonly observed, but there is usually no evidence of epithelial destruction [149]. Tumour cells are $\mathrm{CD}^{+}$, either $\mathrm{CD}^{+}$ (more commonly) or $\mathrm{CD}^{+}$, or in rare instances $\mathrm{CD}^{-}$/ $\mathrm{CD}^{-}$, whilst those expressing CD8 have a cytotoxic profile $\left(\mathrm{TIA}^{+}{ }^{+}\right.$, granzyme $\mathrm{B}^{ \pm}$) $[153,154,156,163]$. Usually, CD56, CD30, CD103 and Epstein-Barr virus are not detected, whilst the Ki67 proliferation index is low e.g. in the range of $5-10 \%[153,154,156,163]$. Tumour cells display TCR $\gamma$ or $\beta$ gene rearrangements and the TCR $\beta$-chain is expressed on the surface in most cases, most notably in $\mathrm{CD} 4^{+}$cases $[153,154,156,163]$.

The condition is clinically indolent, and most patients are still alive with a persistent disease after several years of follow-up [153, 154, 156, 163]. Nevertheless, three cases have been reported where patients died from aggressive T-cell lymphoma several years after being diagnosed [154]. In addition, conventional chemotherapy does not lead to durable clinical and histological responses in such patients and has been associated with high toxicity [153, 154, 156, 163].

Little is known about the mechanisms involved in the pathogenesis of indolent LPD of the gastrointestinal tract. Given the coexistence of autoimmune or inflammatory diseases, it has been speculated that immune dysregulation plays a role in disease pathogenesis [153, 154, 156]. Environmental factors such as diet or infectious agents (e.g. viruses, bacteria) could also be involved in the development of this disease. Human herpes virus 6 (HHV6) was detected in the small intestinal biopsies of one patient by PCR analysis and two patients had positive serology for human T-lymphotropic virus type 1 (HTLV1) at the time of diagnosis, but with no evidence of viral integration in the intestinal biopsies [156]. In addition, no specific disease-associated chromosomal or genetic alterations have been uncovered so far. To date, the origin of indolent digestive T-cell LPDs remains unknown. In a subset of cases, there is expression of CD103, suggesting that such LPDs originate from a 
mucosal T-cell precursor, although further characterisation would be required [164].

\section{Comparison of feline low-grade alimentary lymphoma with human digestive T-cell lymphoma}

The main characteristics of each subtype of human digestive T-cell lymphoma are presented in Table 6.

Although it has been suggested that the feline LGAL most closely resembles enteropathy-associated T-cell lymphoma (EATL; previously designated type I EATL) or monomorphic epitheliotropic intestinal T-cell lymphoma (MEITL; previously designated type II EATL) [6], the authors contend that it has more characteristics in common with indolent digestive T-cell LPDs in humans, according to the latest WHO classification [165]. Clinical, histological and phenotypic features of feline LGAL and human indolent digestive T-cell LPDs are compared in Table 7 and Fig. 5 [149, 153-156, 159].

As previously mentioned, the pathogenesis of human indolent digestive T-cell LPD is poorly understood and the rarity of the disease in humans is the major factor limiting the identification of putative oncogenic events. In contrast, the fact that feline LGAL is more common suggests that it might be a suitable animal model for the human condition, to elucidate some of the pathogenic mechanisms underlying human indolent T-cell LPD of the gastrointestinal tract. Through domestication, humans, dogs and cats share a common environment and therefore display common signatures of coevolution, including epigenetic markers [166, 167]. This might explain why humans and pets are affected by closely-related diseases resulting from variations in genes expression altering conserved functional pathways [168]. The depth and quality of medical phenotyping in pets, associated with their facilitating haplotype structure and the development of genomics tools make them the most valuable mammalian models in medical genetics, including comparative oncology [169]. In the last two decades, dozens of disease-causing variants have been successfully identified in pets, most of them directly informative for humans [168]. Therefore, there is great potential for future research into feline LGAL not only to benefit cats, but also humans.

\section{Conclusion}

Feline low-grade alimentary lymphoma (LGAL) is the most frequent intestinal neoplasm and is characterised

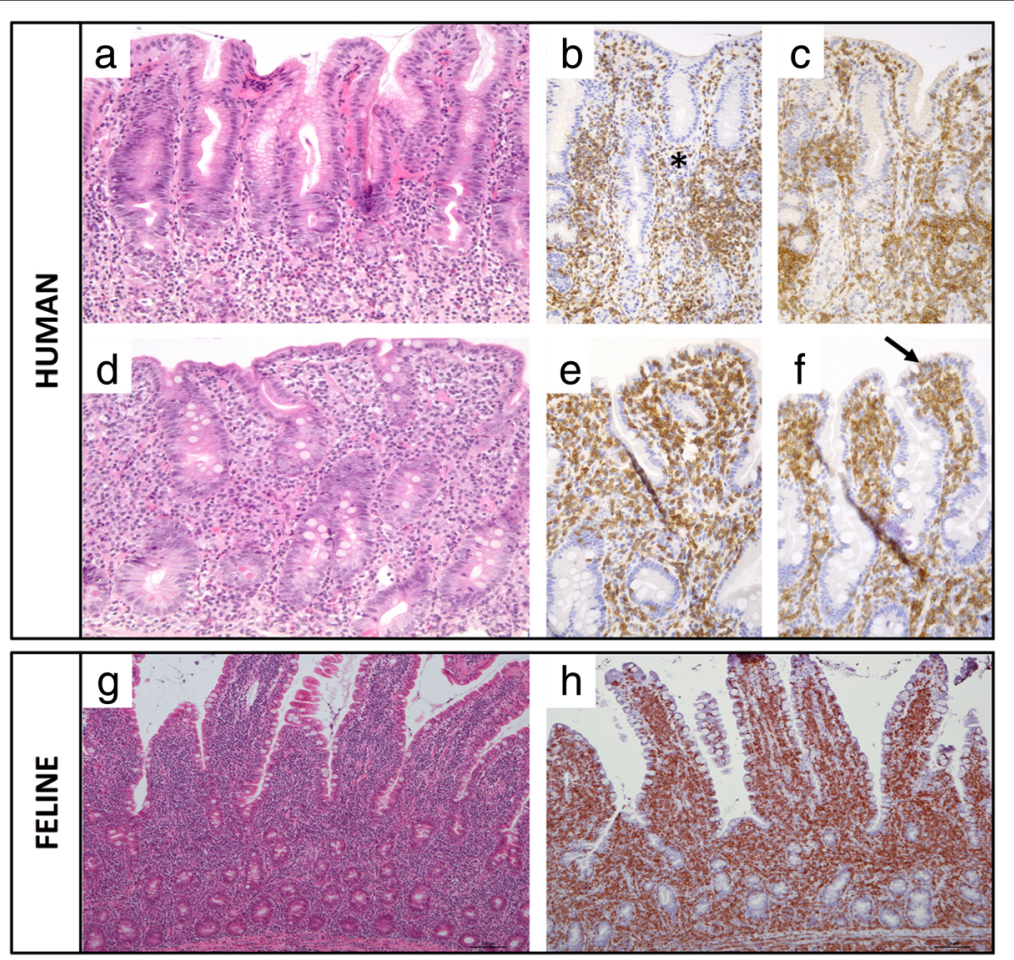

Fig. 5 Comparison of histological and immunohistochemical features of feline low-grade alimentary lymphoma (LGAL) and human indolent digestive T-cell lymphoproliferative disease (LPD). Top Panel: Human indolent CD4 ${ }^{+}$T-cell lymphoproliferative disease of the gastrointestinal tract. Biopsies of the antrum $(\mathbf{a}, \mathbf{b}, \mathbf{c})$ and duodenum $(\mathbf{d}, \mathbf{e}, \mathbf{f})$ show important $\mathrm{CD}^{+}(\mathbf{b}$ and $\mathbf{e})$ and $\mathrm{CD}^{+}(\mathbf{c}$ and $\mathbf{f})$ lymphoid infiltrate into the lamina propria (asterisk), mostly composed by small lymphocytes. Epitheliotropism is mostly absent, with however focal exceptions such as small CD4+ T-cells localized here in the duodenal epithelium (arrow). Bottom Panel: Feline T-cell low-grade alimentary lymphoma. Biopsies of the jejunum show epitheliotropic lymphocytic infiltrate involving the lamina propria (g), exhibiting a $\mathrm{CD}^{+}$phenotype (h) 
by diffuse infiltration of monomorphic neoplastic T-cells in the gastro-intestinal tract. However, diagnosis is still a major challenge, mainly the difficulty in differentiate the condition from inflammatory bowel disease. That said, developments in immunohistochemical analysis and clonality testing have improved the confidence of clinicians in obtaining a correct diagnosis. The pathophysiology of feline LGAL still needs to be elucidated, not least the putative roles of infectious agents, environmental factors as well as genetic events. The most common therapeutic strategy is combination treatment with prednisolone and chlorambucil, and prolonged remission can often be achieved. However, different variations of this therapeutic strategy exist, and standardisation is needed.

Importantly, feline LGAL could be considered to be a potential animal model for human indolent digestive T-cell lymphoproliferative disease. By exploring the pathogenetic mechanisms involved in feline LGAL, it should be possible to improve understanding of the human disease, identify diagnostic and prognostic markers and develop effective therapeutic regimens. More broadly, such an approach could provide insights into the host-pathogen interactions occurring in the gastrointestinal tract and fundamental processes involved in physiological gut immunology.

\begin{abstract}
Abbreviations
AL: Alimentary lymphoma; EATL: Enteropathy-associated T-cell lymphoma; EE: Eosinophilic enteritis; EIL: Epitheliotropic intestinal malignant lymphoma; FcaGHV1: Felis catus gammaherpesvirus 1; FCEAl: Feline chronic enteropathy activity index; FeLV: Feline leukaemia virus; FFPE: Formalin-fixed and paraffinembedded; FIV: Feline immunodeficiency virus; HE: Haematoxylin and eosin; HGAL: High-grade alimentary lymphoma; Hhe: Helicobacter heilmannii; HIV: Human immunodeficiency virus; IBD: Inflammatory bowel disease; IHC: Immunohistochemistry; LGAL: Low-grade alimentary lymphoma; LGLL: Large granular lymphocytic lymphoma; LPD: Lymphoproliferative diseases; LPE: Lymphoplasmacytic enteritis; MALT: Mucosa-associated lymphoid tissue; MEITL: Monomorphic epitheliotropic intestinal T-cell lymphoma; NA: Not available; NHL: Non-hodgkin lymphomas; NK: Natural killer; PARR: PCR for antigen receptor rearrangements; PCR: Polymerase chain reaction; PO: Per Os; SC: Subcutaneous; SIV: Simian immunodeficiency virus; WHO: World Health Organisation
\end{abstract}

\section{Acknowledgments}

The authors thank Dr. Pascaline Pey for providing the ultrasound pictures, and Céline Bleuart and Isabelle Pardo for laboratory processing of gastrointestinal biopsy specimens.

\section{Authors' contributions}

This review, initiated by VF, was a collective work and each author provided a substantial intellectual input to the entirety of the manuscript, from the initial foundations to the final submission of the review. All the authors designed the study under coordination of VF, AJG, LC and $\mathrm{OH}$. All the authors conducted the veterinary or human literature review according to their specialisation: MVP, VF, LT, GB, JBe and AJG for veterinary internal medicine and oncology; SLP for virology; MD, MOS and JBr for histology; and LC, GM, CC, NCB and OH for human medicine. MVP, LT and VF supervised and analysed the veterinary literature review; $\mathrm{LC}$ and $\mathrm{OH}$ the human medicine literature review. All the authors drafted or revised the manuscript, especially in relation to their area of specialisation. All the authors read and approved the final version. Equal input was received from all authors.
Ethics approval and consent to participate

Not applicable.

\section{Consent for publication}

Not applicable.

\section{Competing interests}

AJG's academic post at the University of Liverpool is financially supported by Royal Canin. Otherwise, the authors declare that they had no conflicts of interests with respect to their authorship or the publication of this article.

\section{Publisher's Note}

Springer Nature remains neutral with regard to jurisdictional claims in published maps and institutional affiliations.

\section{Author details}

${ }^{1}$ Université Paris-Est, École Nationale Vétérinaire d'Alfort, 7 Avenue du Général de Gaulle, 94700 Maisons-Alfort, France. ${ }^{2}$ Hematology Department, Hôpital Universitaire Necker - Enfants Malades, Assistance Publique Hôpitaux de Paris (APHP), Paris, France. ${ }^{3}$ Université Paris Descartes, Sorbonne Paris Cité, Paris, France. ${ }^{4}$ INSERM UMR 1163, CNRS ERL 8254, Institut Imagine, Paris, France. ${ }^{5}$ Internal Medicine Department, Université Paris-Est, École Nationale Vétérinaire d'Alfort, 7 Avenue du Général de Gaulle, 94700 Maisons-Alfort, France. 'UMR 1161 Virologie, INRA-ENVA-ANSES, Université Paris-Est, École Nationale Vétérinaire d'Alfort, Maisons-Alfort, France. ${ }^{7}$ Anatomical Pathology Department, Université de Toulouse, École Nationale Vétérinaire de Toulouse, 23 Chemin des Capelles, 31076 Toulouse Cedex, France. ${ }^{8}$ Pathology Department, Hôpital Universitaire Necker - Enfants Malades, Assistance Publique - Hôpitaux de Paris (APHP), Université Paris Descartes, Sorbonne Paris Cité, Paris, France. ${ }^{9}$ INSERM 1163, Institut Imagine, Site Hôpital Universitaire Necker - Enfants Malades, Paris, France. ${ }^{10}$ UMR 1163, Laboratory of Intestinal Immunity, INSERM, Paris, France.

${ }^{11}$ Gastroenterology Department, Hôpital Européen Georges Pompidou, Assistance Publique - Hôpitaux de Paris (APHP), Université Paris Descartes, Sorbonne Paris Cité, Paris, France. ${ }^{12}$ INSERM UMR 1163, Institut Imagine, Paris, France. ${ }^{13}$ Inserm U955-E10 BNMS, IMRB, Université Paris-Est, École Nationale Vétérinaire d'Alfort, 94000 Maisons-Alfort, France. ${ }^{14}$ Institute of Ageing and Chronic Disease, University of Liverpool, Leahurst Campus, Chester High Road, Neston CH64 7TE, UK.

Received: 2 May 2018 Accepted: 28 September 2018

Published online: 11 October 2018

References

1. Twomey LN, Compendium AA. Cytodiagnosis of feline lymphoma. Compendium. 2005;27:1.

2. Richter KP. Feline gastrointestinal lymphoma. Vet Clin North Am Small Anim Pract. 2003:33:1083-98.

3. Ettinger SN. Principles of treatment for feline lymphoma. Clin Tech Small Anim Pract. 2003;18:98-102.

4. Gabor LJ, Malik R, Canfield PJ. Clinical and anatomical features of lymphosarcoma in 118 cats. Aust Vet J. 1998;76:725-32.

5. Vail DM, Moore AS, Ogilvie GK, Volk LM. Feline lymphoma (145 cases): proliferation indices, cluster of differentiation 3 immunoreactivity, and their association with prognosis in 90 cats. J Vet Intern Med. 1998;12:349-54.

6. Moore PF, Rodriguez-Bertos A, Kass PH. Feline gastrointestinal lymphoma: mucosal architecture, immunophenotype, and molecular clonality. Vet Pathol. 2011;49:658-68.

7. Guillermo CC. What is new on feline lymphoma? J Feline Med Surg. 2001;3:171-6.

8. Barrs V, Beatty J. Feline alimentary lymphoma: 1. Classification, risk factors, clinical signs and non-invasive diagnostics. J Feline Med Surg. 2012;14:182-90.

9. Hadden AG, Cotter SM, Rand W, Moore AS, Davis RM, Morrissey P. Efficacy and toxicosis of VELCAP-C treatment of lymphoma in cats. J Vet Intern Med. 2008;22:153-7.

10. Delverdier M, Bourges-Abella N, Raymond-Letron I, Trumel C, DegorceRubiales F, Poujade A, et al. Immunohistochimie des lymphomes gastrointestinaux du chat. Revue Méd Vét. 2010;161:225-32.

11. Wilson HM. Feline alimentary lymphoma: demystifying the enigma. Top Companion Anim Med. 2008;23:177-84.

12. Pohlman LM, Higginbotham ML, Welles EG. Classification of feline gastrointestinal lymphoma. Adv Small Ani Med and Surg. 2010;23:5. 
13. Sato H, Fujino Y, Chino J, Takahashi M, Fukushima K, Goto-Koshino Y, et al. Prognostic analyses on anatomical and morphological classification of feline lymphoma. J Vet Med Sci. 2014;76:807-11.

14. Willard MD. Alimentary neoplasia in geriatric dogs and cats. Vet Clin North Am Small Anim Pract. 2012;42:693-706.

15. Daniaux LA, Laurenson MP, Marks SL, Moore PF, Taylor SL, Chen RX, et al. Ultrasonographic thickening of the muscularis propria in feline small intestinal small cell T-cell lymphoma and inflammatory bowel disease. J Feline Med Surg. 2013;16:89-98.

16. Kristal O, Lana SE, Ogilvie GK, Rand WM, Cotter SM, Moore AS. Single agent chemotherapy with doxorubicin for feline lymphoma: a retrospective study of 19 cases (1994-1997). J Vet Inter Med. 2001;15:125-30.

17. Milner RJ, Peyton J, Cooke K, Fox LE, Gallagher A, Gordon P, et al. Response rates and survival times for cats with lymphoma treated with the University of Wisconsin-Madison chemotherapy protocol: 38 cases (19962003). J Am Vet Med Assoc. 2005;227:1118-22.

18. Chino J, Fujino Y, Kobayashi T, Kariya K, Goto-Koshino Y, Ohno K, et al. Cytomorphological and immunological classification of feline lymphomas: clinicopathological features of 76 cases. J Vet Med Sci. 2013;75:701-7.

19. Swanson CM, Smedley RC, Saavedra PV, Kiupel M, Kitchell BE. Expression of the $\mathrm{BCl}-2$ apoptotic marker in cats diagnosed with inflammatory bowel disease and gastrointestinal lymphoma. J Feline Med Surg. 2012;14:741-5.

20. Fondacaro JV, Richter KP, Carpenter JL, Hart JR, Hill SL, Fettman MJ. Feline gastrointestinal lymphoma: 67 cases (1988-1996). Eur J Comp Gastroenterol. 1999:4:5-11.

21. Harris NL, Jaffe ES, Stein H, Banks PM, Chan JK, Cleary ML, et al. A revised European-American classification of lymphoid neoplasms: a proposal from the international lymphoma study group. Blood. 1994;84:1361-92.

22. Valli VE, Jacobs RM, Norris A, Couto CG, Morrison WB, McCaw D, et al. The histologic classification of 602 cases of feline lymphoproliferative disease using the National Cancer Institute working formulation. J Vet Diagn Investig. 2000;12:295-306.

23. Wolfesberger B, Skor O, Hammer SE, Flickinger I, Kleiter M, Rütgen BC, et al. Does categorisation of lymphoma subtypes according to the World Health Organization classification predict clinical outcome in cats. J Feline Med Surg. 2017;19:897-906.

24. Delabie J, Holte H, Vose JM, Ullrich F, Jaffe ES, Savage KJ, et al. Enteropathyassociated T-cell lymphoma: clinical and histological findings from the international peripheral T-cell lymphoma project. Blood. 2011;118:148-55.

25. Ondrejka S, Jagadeesh D. Enteropathy-associated T-cell lymphoma. Curr Hematol Malig Rep. 2016;11:504-13.

26. Sapierzyński R, Jankowska U, Jagielski D, Kliczkowska-Klarowicz K. Large granular lymphoma in six cats. Pol J Vet Sci. 2015;18:163-9.

27. Krick EL, Little L, Patel R, Shofer FS, Sorenmo K, Clifford CA, et al. Description of clinical and pathological findings, treatment and outcome of feline large granular lymphocyte lymphoma (1996-2004). Vet Comp Oncol. 2008;6:102-10.

28. Russell KJ, Beatty JA, Dhand N, Gunew M, Lingard AE, Baral RM, et al. Feline low-grade alimentary lymphoma: how common is it? J Feline Med Surg. 2012;14:910-2

29. Louwerens $M$, London CA, Pedersen NC, Lyons LA. Feline lymphoma in the post-feline leukemia virus era. J Vet Intern Med. 2005;19:329-35.

30. Fujino Y, Liao C-P, Zhao YS, Pan J, Mathes LE, Hayes KA, et al. Identification of a novel common proviral integration site, flit-1, in feline leukemia virus induced thymic lymphoma. Virology. 2009;386:16-22.

31. Nesina S, Katrin Helfer-Hungerbuehler A, Riond B, Boretti FS, Willi B, Meli ML, et al. Retroviral DNA--the silent winner: blood transfusion containing latent feline leukemia provirus causes infection and disease in naïve recipient cats. Retrovirology. 2015;12:105.

32. Tsatsanis C, Fulton R, Nishigaki K, Tsujimoto H, Levy L, Terry A, et al. Genetic determinants of feline leukemia virus-induced lymphoid tumors: patterns of proviral insertion and gene rearrangement. J Virol. 1994;68:8296-303.

33. Jackson ML, Wood SL, Misra V, Haines DM. Immunohistochemical identification of B and T lymphocytes in formalin-fixed, paraffin-embedded feline lymphosarcomas: relation to feline leukemia virus status, tumor site, and patient age. Can J Vet Res. 1996;60:199-204.

34. Callanan JJ, Jones BA, Irvine J, Willett BJ, McCandlish IA, Jarrett O. Histologic classification and immunophenotype of lymphosarcomas in cats with naturally and experimentally acquired feline immunodeficiency virus infections. Vet Pathol. 1996;33:264-72.

35. Mikkers $\mathrm{H}$, Berns A. Retroviral insertional mutagenesis: tagging cancer pathways. Adv Cancer Res. 2003;88:53-99.
36. Weiss ATA, Klopfleisch R, Gruber AD. Prevalence of feline leukaemia provirus DNA in feline lymphomas. J Feline Med Surg. 2010;12:929-35.

37. Stützer B, Simon K, Lutz H, Majzoub M, Hermanns W, Hirschberger J, et al. Incidence of persistent viraemia and latent feline leukaemia virus infection in cats with lymphoma. J Feline Med Surg. 2011;13:81-7.

38. Mahony OM, Moore AS, Cotter SM, Engler SJ, Brown D, Penninck DG. Alimentary lymphoma in cats: 28 cases (1988-1993). J Am Vet Med Assoc. 1995;207:1593-8.

39. Pohlman LM, Higginbotham ML, Welles EG, Johnson CM. Immunophenotypic and histologic classification of 50 cases of feline gastrointestinal lymphoma. Vet Pathol. 2009;46:259-68.

40. Zwahlen CH, Lucroy MD, Kraegel SA, Madewell BR. Results of chemotherapy for cats with alimentary malignant lymphoma: 21 cases (1993-1997). J Am Vet Med Assoc. 1998:213:1144-9.

41. Feichtinger H, Putkonen P, Parravicini C, Li SL, Kaaya EE, Böttiger D, et al. Malignant lymphomas in cynomolgus monkeys infected with simian immunodeficiency virus. Am J of Pathol. 1990;137:1311-5.

42. Ramsay AD, Giddings J, Baskerville A, Cranage MP. Phenotypic analysis of malignant lymphoma in simian immunodeficiency virus infection using anti-human antibodies. J Pathol. 1991;164:321-8.

43. Levine AM. Acquired immunodeficiency syndrome-related lymphoma: clinical aspects. Semin Oncol. 2000;27:442-53.

44. Beatty JA, Lawrence CE, Callanan JJ, Grant CK, Gault EA, Neil JC, et al. Feline immunodeficiency virus (FIV)-associated lymphoma: a potential role for immune dysfunction in tumourigenesis. Vet Immunol Immunopathol. 1998; 65:309-22.

45. Lutz H, Pedersen NC, Theilen GH. Course of feline leukemia virus infection and its detection by enzymelinked immunosorbent assay and monoclonal antibodies. Am J Vet Res. 1983:44:2054-9.

46. Court EA, Watson AD, Peaston AE. Retrospective study of 60 cases of feline lymphosarcoma. Aust Vet J. 1997;75:424-7.

47. Kaye S, Wang W, Miller C, McLuckie A, Beatty JA, Grant CK, et al. Role of feline immunodeficiency virus in lymphomagenesis--going alone or colluding? ILAR J. 2016;57:24-33.

48. Plummer M, de Martel C, Vignat J, Ferlay J, Bray F, Franceschi S. Global burden of cancers attributable to infections in 2012: a synthetic analysis. Lancet Glob Health. 2016:4:609-16.

49. Parkin DM. The global health burden of infection-associated cancers in the year 2002. Int J Cancer. 2006;118:3030-44.

50. McLuckie AJ, Barrs VR, Lindsay S, Aghazadeh M, Sangster C, Beatty JA. Molecular diagnosis of Felis catus Gammaherpesvirus 1 (FcaGHV1) infection in cats of known retrovirus status with and without lymphoma. Viruses. 2018;10:128.

51. Simpson KW, Strauss-Ayali D, Scanziani E, Straubinger RK, McDonough PL, Straubinger AF, et al. Helicobacter felis infection is associated with lymphoid follicular hyperplasia and mild gastritis but normal gastric secretory function in cats. Infect Immun. 2000;68:779-90.

52. Bridgeford EC, Marini RP, Feng Y, Parry NMA, Rickman B, Fox JG. Gastric helicobacter species as a cause of feline gastric lymphoma: a viable hypothesis. Vet Immunol Immunopathol. 2008;123:106-13.

53. Farinha P, Gascoyne RD. Helicobacter pylori and MALT lymphoma. Gastroenterology. 2005;128:1579-605.

54. Wang F, Meng W, Wang B, Qiao L. Helicobacter pylori-induced gastric inflammation and gastric cancer. Cancer Lett. 2014;345:196-202.

55. Rossi G, Rossi M, Vitali CG, Fortuna D, Burroni D, Pancotto L, et al. A conventional beagle dog model for acute and chronic infection with helicobacter pylori. Infect Immun. 1999;67:3112-20.

56. Hoehne SN, McDonough SP, Rishniw M, Simpson KW. Identification of mucosa-invading and intravascular Bacteria in feline small intestinal lymphoma. Vet Pathol. 2017;54:234-41.

57. Moore PF, Woo JC, Vernau W, Kosten S, Graham PS. Characterization of feline T cell receptor gamma (TCRG) variable region genes for the molecular diagnosis of feline intestinal T cell lymphoma. Vet Immunol Immunopathol. 2005;106:167-78.

58. Briscoe KA, Krockenberger M, Beatty JA, Crowley A, Dennis MM, Canfield PJ, et al. Histopathological and immunohistochemical evaluation of 53 cases of feline lymphoplasmacytic enteritis and low-grade alimentary lymphoma. J Comp Pathol. 2011;145:187-98

59. Lingard AE, Briscoe K, Beatty JA, Moore AS, Crowley AM, Krockenberger $M$, et al. Low-grade alimentary lymphoma: clinicopathological findings and response to treatment in 17 cases. J Feline Med Surg. 2009:11:692700 . 
60. Carreras JK, Goldschmidt M, Lamb M, McLear RC, Drobatz KJ, Sorenmo KU. Feline epitheliotropic intestinal malignant lymphoma: 10 cases (1997-2000). J Vet Intern Med. 2003;17:326-31.

61. Kiupel M, Smedley RC, Pfent C, Xie Y, Xue Y, Wise AG, et al. Diagnostic algorithm to differentiate lymphoma from inflammation in feline small intestinal biopsy samples. Vet Pathol. 2011;48:212-22.

62. Waly NE, Gruffydd-Jones TJ, Stokes CR, Day MJ. Immunohistochemical diagnosis of alimentary lymphomas and severe intestinal inflammation in cats. J Comp Pathol. 2005;133:253-60.

63. Castro-López J, Teles M, Fierro C, Allenspach K, Planellas M, Pastor J. Pilot study: duodenal MDR1 and COX2 gene expression in cats with inflammatory bowel disease and low-grade alimentary lymphoma. J Feline Med Surg. 2017;207:214.

64. Hart JR, Shaker E, Patnaik AK, Garvey MS. Lymphocytic-plasmacytic enterocolitis in cats: 60 cases (19881990). Am Anim Hosp Assoc. 1994;30:505-14.

65. Krecic MR, Black SS. Epitheliotropic T-cell gastrointestinal tract lymphosarcoma with metastases to lung and skeletal muscle in a cat. J Am Vet Med Assoc. 2000;216:524-9.

66. French RA, Seitz SE, Valli VE. Primary epitheliotropic alimentary T-cell lymphoma with hepatic involvement in a dog. Vet Pathol. 1996;33:349-52.

67. Chott A, Dragosics B, Radaszkiewicz T. Peripheral T-cell lymphomas of the intestine. Am J Pathol. 1992;141:1361-71.

68. Dieter RS, Duque K. Enterotherapy associated T-cell lymphoma: a case report and literature review. WMJ. 2000;99:28-31.

69. Ohsawa M, Fukushima H, Ikura $Y$, Inoue T, Shirai N, Sugama $Y$, et al. Expression of cyclooxygenase-2 in Hodgkin's lymphoma: its role in cel proliferation and angiogenesis. Leuk Lymphoma. 2006;47:1863-71.

70. Panwala $\mathrm{CM}$, Jones JC, Viney JL. A novel model of inflammatory bowel disease: mice deficient for the multiple drug resistance gene, mdr1a, spontaneously develop colitis. J Immunol. 1998;161:5733-44.

71. Bertone ER, Snyder LA, Moore AS. Environmental tobacco smoke and risk of malignant lymphoma in pet cats. Am J Epidemiol. 2002;156:268-73.

72. Kiselow MA, Rassnick KM, McDonough SP, Goldstein RE, Simpson KW, Weinkle TK, et al. Outcome of cats with low-grade lymphocytic lymphoma: 41 cases (1995-2005). J Am Vet Med Assoc. 2008;232:405-10.

73. Rissetto K, Villamil JA, Selting KA, Tyler J, Henry CJ. Recent trends in feline intestinal neoplasia: an epidemiologic study of 1,129 cases in the veterinary medical database from 1964 to 2004. J Am Anim Hosp Assoc. 2011;47:28-36.

74. Bernardin F, Martinez Rivera L, Ragetly G, Gomes E, Hernandez J. Spontaneous gastrointestinal perforation in cats: a retrospective study of 13 cases. J Feline Med Surg. 2015;17:873-9.

75. Gieger T. Alimentary lymphoma in cats and dogs. Vet Clin North Am Small Anim Pract. 2011;41:419-32.

76. Smith AL, Wilson AP, Hardie RJ, Krick EL, Schmiedt CW. Perioperative complications after full-thickness gastrointestinal surgery in cats with alimentary lymphoma. Vet Surg. 2011;40:849-52.

77. Evans SE, Bonczynski JJ, Broussard JD, Han E, Baer KE. Comparison of endoscopic and full-thickness biopsy specimens for diagnosis of inflammatory bowel disease and alimentary tract lymphoma in cats. J Am Vet Med Assoc. 2006;229:1447-50.

78. Jergens AE, Crandell JM, Evans R, Ackermann M, Miles KG, Wang C. A clinical index for disease activity in cats with chronic enteropathy. J Vet Intern Med. 2010;24:1027-33.

79. Jergens AE. Feline idiopathic inflammatory bowel disease: what we know and what remains to be unraveled. J Feline Med Surg. 2012;14:445-58

80. Noland EL, Kiupel M. Coexpression of CD3 and CD20 in canine Enteropathyassociated T-cell lymphoma. Vet Pathol. 2018;55:241-4.

81. Jackson ML, Haines DM, Meric SM, Misra V. Feline leukemia virus detection by immunohistochemistry and polymerase chain reaction in formalin-fixed, paraffin-embedded tumor tissue from cats with lymphosarcoma. Can J Vet Res. 1993;57:269-76.

82. Gianella P, Pietra M, Crisi PE, Famigli Bergamini P, Fracassi F, Morini M, et al. Evaluation of clinicopathological features in cats with chronic gastrointestinal signs. Pol J Vet Sci. 2017;20:403-10.

83. Simpson KW, Fyfe J, Cornetta A, Sachs A, Strauss-Ayali D, Lamb SV, et al. Subnormal concentrations of serum cobalamin (vitamin B12) in cats with gastrointestinal disease. J Vet Intern Med. 2001;15:26-32.

84. Tucker S, Penninck DG, Keating JH, Webster CRL. Clinicopathological and ultrasonographic features of cats with eosinophilic enteritis. J Feline Med Surg. 2014;16:950-6.
85. Andrews C, Operacz M, Maes R, Kiupel M. Cross lineage rearrangement in feline Enteropathy-associated T-cell lymphoma. Vet Pathol. 2016;53:559-62.

86. Ruaux CG, Steiner JM, Williams DA. Early biochemical and clinical responses to cobalamin supplementation in cats with signs of gastrointestinal disease and severe hypocobalaminemia. J Vet Intern Med. 2005;19:155-60.

87. Burke KF, Broussard JD, Ruaux CG, Suchodolski JS, Williams DA, Steiner JM. Evaluation of fecal a1-proteinase inhibitor concentrations in cats with idiopathic inflammatory bowel disease and cats with gastrointestinal neoplasia. Vet J. 2013;196:189-96.

88. Soare T, Noble P-J, Hetzel U, Fonfara S, Kipar A. Paraneoplastic syndrome in haemophagocytic histiocytic sarcoma in a dog. J Comp Pathol. 2012; 146:168-74.

89. Declue AE, Delgado C, Chang C-H, Sharp CR. Clinical and immunologic assessment of sepsis and the systemic inflammatory response syndrome in cats. J Am Vet Med Assoc. 2011;238:890-7.

90. Maunder CL, Day MJ, Hibbert A, Steiner JM, Suchodolski JS, Hall EJ. Serum cobalamin concentrations in cats with gastrointestinal signs: correlation with histopathological findings and duration of clinical signs. J Feline Med Surg. 2012;14:686-93.

91. Ibarrola P, Blackwood L, Graham PA, Evans H, German AJ. Hypocobalaminaemia is uncommon in cats in the United Kingdom. J Feline Med Surg. 2005;7:341-8.

92. Reed N, Gunn-Moore D, Simpson K. Cobalamin, folate and inorganic phosphate abnormalities in ill cats. J Feline Med Surg. 2007;9:278-88.

93. Barron PM, Mackie JT, Evans NA, Langer N. Serum cobalamin concentrations in healthy cats and cats with non-alimentary tract illness in Australia. Aust Vet J. 2009;87:280-3.

94. Puig J, Cattin I, Seth M. Concurrent diseases in hyperthyroid cats undergoing assessment prior to radioiodine treatment. J Feline Med Surg. 2015:17:537-42

95. Zwingenberger AL, Marks SL, Baker TW, Moore PF. Ultrasonographic evaluation of the muscularis propria in cats with diffuse small intestinal lymphoma or inflammatory bowel disease. J Vet Intern Med. 2010;24:289-92.

96. Pope KV, Tun AE, McNeill CJ, Brown DC, Krick EL. Outcome and toxicity assessment of feline small cell lymphoma: 56 cases (2000-2010). Vet Med Sci. 2015;1:51-62.

97. Stein TJ, Pellin M, Steinberg H, Chun R. Treatment of feline gastrointestinal small-cell lymphoma with chlorambucil and glucocorticoids. J Am Anim Hosp Assoc. 2010;46:413-7.

98. Ripollés T, Rausell N, Paredes JM, Grau E, Martínez MJ, Vizuete J. Effectiveness of contrast-enhanced ultrasound for characterisation of intestinal inflammation in Crohn's disease: a comparison with surgical histopathology analysis. J Crohns Colitis. 2013;7:120-8.

99. Penninck D, d'Anjou M-A. Gastrointestinal tract. In: Penninck D, d'Anjou M-A editors. Atlas of small animal ultrasonography, second edition. lowa: Wiley; 2015. p. 256-308.

100. Linton M, Nimmo JS, Norris JM, Churcher R, Haynes S, Zoltowska A, et al. Feline gastrointestinal eosinophilic sclerosing fibroplasia: 13 cases and review of an emerging clinical entity. J Feline Med Surg. 2015;17:392-404.

101. Gaschen L. Ultrasonography of small intestinal inflammatory and neoplastic diseases in dogs and cats. Vet Clin North Am Small Anim Pract. 2011:41:329-44.

102. Diana A, Pietra M, Guglielmini C, Boari A, Bettini G, Cipone M Ultrasonographic and pathologic features of intestinal smooth muscle hypertrophy in four cats. Vet Radiol Ultrasound. 2003;44:566-9.

103. Jergens $A E$, Willard MD, Allenspach K. Maximizing the diagnostic utility of endoscopic biopsy in dogs and cats with gastrointestinal disease. Vet J. 2016;214:50-60.

104. Washabau RJ, Day MJ, Willard MD, Hall EJ, Jergens AE, Mansell J, et al. Endoscopic, biopsy, and histopathologic guidelines for the evaluation of gastrointestinal inflammation in companion animals. J Vet Intern Med. 2010;24:10-26.

105. Sum S, Ward CR. Flexible endoscopy in small animals. Vet Clin North Am Small Anim Pract. 2009:39:881-902.

106. Scott KD, Zoran DL, Mansell J, Norby B, Willard MD. Utility of endoscopic biopsies of the duodenum and ileum for diagnosis of inflammatory bowel disease and small cell lymphoma in cats. J Vet Intern Med. 2011;25:1253-7.

107. Barrs VR, Beatty JA. Feline alimentary lymphoma: 2. Further diagnostics, therapy and prognosis. J Feline Med Surg. 2012;14:191-201.

108. Norsworthy GD, Estep JS, Hollinger C, Steiner JM, Lavallee JO, Gassler LN, et al. Prevalence and underlying causes of histologic abnormalities in cats suspected to have chronic small bowel disease: 300 cases (2008-2013). J Am Vet Med Assoc. 2015;247:629-35 
109. Ku C-K, Kass PH, Christopher MM. Cytologic-histologic concordance in the diagnosis of neoplasia in canine and feline lymph nodes: a retrospective study of 367 cases. Vet Comp Oncol. 2017;15:1206-17.

110. Mangelsdorf S, Teske E, Bomhard von W, Stockhaus C. Cytology of endoscopically obtained biopsies for the diagnosis of chronic intestinal diseases in cats. Tierarztl Prax Ausg K Kleintiere Heimtiere. 2015;43:15-22.

111. Burkhard MJ, Bienzle D. Making sense of lymphoma diagnostics in small animal patients. Vet Clin North Am Small Anim Pract. 2013;43:1331-47.

112. Sabattini S, Bottero E, Turba ME, Vicchi F, Bo S, Bettini G. Differentiating feline inflammatory bowel disease from alimentary lymphoma in duodenal endoscopic biopsies. J Small Anim Pract. 2016;57:396-401.

113. Day MJ, Bilzer T, Mansell J, Wilcock B, Hall EJ, Jergens A, et al. Histopathological standards for the diagnosis of gastrointestinal inflammation in endoscopic biopsy samples from the dog and cat: a report from the world small animal veterinary association gastrointestinal standardization group. J Comp Pathol. 2008;138:143.

114. Roccabianca P, Woo JC, Moore PF. Characterization of the diffuse mucosal associated lymphoid tissue of feline small intestine. Vet Immunol Immunopathol. 2000;75:27-42.

115. Waly N, Gruffydd-Jones TJ, Stokes CR, Day MJ. The distribution of leucocyte subsets in the small intestine of healthy cats. J Comp Pathol. 2001;124:172-82.

116. Roccabianca P, Vernau W, Caniatti M, Moore PF. Feline large granular lymphocyte (LGL) lymphoma with secondary leukemia: primary intestinal origin with predominance of a CD3/CD8(alpha)(alpha) phenotype. Vet Pathol. 2006:43:15-28.

117. Willard MD, Jergens AE, Duncan RB, Leib MS, McCracken MD, DeNovo RC, et al. Interobserver variation among histopathologic evaluations of intestinal tissues from dogs and cats. J Am Vet Med Assoc. 2002;220:1177-82.

118. Renshaw AA. Measuring and reporting errors in surgical pathology. Lessons from gynecologic cytology. Am J Clin Pathol. 2001;115:338-41.

119. Kleinschmidt S, Harder J, Nolte I, Marsilio S, Hewicker-Trautwein M. Chronic inflammatory and noninflammatory diseases of the gastrointestinal tract in cats: diagnostic advantages of full-thickness intestinal and extraintestinal biopsies. J Feline Med Surg. 2010;12:97-103.

120. Patterson-Kane JC, Kugler BP, Francis K. The possible prognostic significance of immunophenotype in feline alimentary lymphoma: a pilot study. J Comp Pathol. 2004;130:220-2.

121. Gerdes J, Lemke H, Baisch H, Wacker HH, Schwab U, Stein H. Cell cycle analysis of a cell proliferationassociated human nuclear antigen defined by the monoclonal antibody Ki-67. J Immunol. 1984;133:1710-5.

122. Kim KH, Sederstrom JM. Assaying cell cycle status using flow cytometry. Curr Protoc Mol Biol. 2015;111:11-28.

123. Matnani RG, Stewart RL, Pulliam J, Jennings CD, Kesler M. Peripheral T-cell lymphoma with aberrant expression of CD19, CD20, and CD79a: case report and literature review. Case Rep Hematol. 2013:183134-5.

124. Rahemtullah A, Longtine JA, Harris NL, Dorn M, Zembowicz A, QuintanillaFend L, et al. CD20+ T-cell lymphoma: clinicopathologic analysis of 9 cases and a review of the literature. Am J Surg Pathol. 2008;32:1593-607.

125. Misra DS, Bhardwaj M, Bahuguna G, Malhotra V. An unusual case of enteropathy-associated T-cell lymphoma with CD20 positivity. Indian J Pathol Microbiol. 2014;57:658-9.

126. Quintanilla-Martinez L, Preffer F, Rubin D, Ferry JA, Harris NL. CD20+ T-cell lymphoma, neoplastic transformation of a normal T-cell subset. Am J Clin Pathol. 1994:102:483-9.

127. Keller SM, Vernau W, Moore PF. Clonality testing in veterinary medicine: a review with diagnostic guidelines. Vet Pathol. 2016:53:711-25.

128. Hammer SE, Groiss S, Fuchs-Baumgartinger A, Nedorost N, Gress V, Luckschander-Zeller N, et al. Characterization of a PCR-based lymphocyte clonality assay as a complementary tool for the diagnosis of feline lymphoma. Vet Comp Oncol. 2017;15:1354-69.

129. Werner JA, Woo JC, Vernau W, Graham PS, Grahn RA, Lyons LA, et al. Characterization of feline immunoglobulin heavy chain variable region genes for the molecular diagnosis of B-cell neoplasia. Vet Pathol. 2005;42:596-607.

130. Evans PAS, Pott C, Groenen PJTA, Salles G, Davi F, Berger F, et al. Significantly improved PCR-based clonality testing in B-cell malignancies by use of multiple immunoglobulin gene targets. Report of the BIOMED2 concerted action BHM4-CT98-3936. Leukemia. 2007;21:207-14.

131. Pelicci PG, Knowles DM, Dalla FR. Lymphoid tumors displaying rearrangements of both immunoglobulin and T cell receptor genes. J Exp Med. 1985;162:1015-24.
132. Krejci O, Prouzova Z, Horvath O, Trka J, Hrusak O. Cutting edge: TCR delta gene is frequently rearranged in adult B lymphocytes. J Immunol. 2003;171:524-7.

133. Valli VE, Vernau W, de Lorimier L-P, Graham PS, Moore PF. Canine indolent nodular lymphoma. Vet Pathol 2006;43:241-256.

134. van Dongen JJ, Wolvers-Tettero IL. Analysis of immunoglobulin and T cell receptor genes. Part II: possibilities and limitations in the diagnosis and management of lymphoproliferative diseases and related disorders. Clin Chim Acta 1991;198:93-174.

135. Weiss ATA, Klopfleisch R, Gruber AD. T-cell receptor $\gamma$ chain variable and joining region genes of subgroup 1 are clonally rearranged in feline $B$ - and T-cell lymphoma. J Comp Pathol. 2011;144:123-34.

136. Gress V, Wolfesberger B, Fuchs-Baumgartinger A, Nedorost N, Saalmüller A, Schwendenwein I, et al. Characterization of the T-cell receptor gamma chain gene rearrangements as an adjunct tool in the diagnosis of Tcell lymphomas in the gastrointestinal tract of cats. Res Vet Sci. 2016;107:261-6.

137. Doorenspleet ME, Westera L, Peters CP, Hakvoort TBM, Esveldt RE, Vogels E, et al. Profoundly expanded T-cell clones in the inflamed and uninflamed intestine of patients with Crohn's disease. J Crohns Colitis. 2017;11:831-9.

138. Gouldin ED, Mullin C, Morges M, Mehler SJ, de Lorimier L-P, Oakley C, et al. Feline discrete high-grade gastrointestinal lymphoma treated with surgical resection and adjuvant CHOP-based chemotherapy: retrospective study of 20 cases. Vet Comp Oncol. 2017;15:328-35.

139. Almakdisi T, Massoud S, Makdisi G. Lymphomas and chylous ascites: review of the literature. Oncologist. 2005;10:632-5.

140. Wofford JA, Zollers B, Rhodes L, Bell M, Heinen E. Evaluation of the safety of daily administration of capromorelin in cats. J Vet Pharmacol Ther. 2018;41: 324-33.

141. Zollers B, Rhodes L, Heinen E. Capromorelin oral solution (ENTYCE ${ }^{\oplus}$ ) increases food consumption and body weight when administered for 4 consecutive days to healthy adult beagle dogs in a randomized, masked, placebo controlled study. BMC Vet Res. 2017;13:10.

142. White HK, Petrie CD, Landschulz W, MacLean D, Taylor A, Lyles K, et al. Effects of an oral growth hormone secretagogue in older adults. J Clin Endocrinol Metab. 2009:94:1198-206.

143. Gustafson TL, Villamil A, Taylor BE, Flory A. A retrospective study of feline gastric lymphoma in 16 chemotherapy-treated cats. J Am Anim Hosp Assoc. 2014;50:46-52.

144. Malik R, Gabor LJ, Foster SF, McCorkell BE, Canfield PJ. Therapy for Australian cats with lymphosarcoma. Aust Vet J. 2001;79:808-17.

145. Mooney SC, Hayes AA, MacEwen EG, Matus RE, Geary A, Shurgot BA. Treatment and prognostic factors in lymphoma in cats: 103 cases (19771981). J Am Vet Med Assoc. 1989;194:696-702

146. Thomas R. Cytogenomics of feline cancers: advances and opportunities. Vet Sci. 2015;2:246-58

147. Mwangi W, de Figueiredo P, Criscitiello MF. One health: addressing global challenges at the nexus of human, animal, and environmental health. PLoS Pathog 2016;12:e1005731.

148. Yuhki N, Beck T, Stephens R, Neelam B, O'Brien SJ. Comparative genomic structure of human, dog, and cat MHC: HLA, DLA, and FLA. J Hered. 2007; 98:390-9.

149. Foukas PG, de Leval L. Recent advances in intestinal lymphomas. Histopathology. 2015;66:112-36.

150. Koch $P$, del Valle F, Berdel WE, Willich NA, Reers B, Hiddemann W, et al. Primary gastrointestinal nonHodgkin's lymphoma: I. anatomic and histologic distribution, clinical features, and survival data of 371 patients registered in the German multicenter study GIT NHL 01/92. J Clin Oncol. 2001;19:386173.

151. Andrews CN, John Gill M, Urbanski SJ, Stewart D, Perini R, Beck P. Changing epidemiology and risk factors for gastrointestinal non-Hodgkin's lymphoma in a north American population: population-based study. Am J Gastroenterol. 2008;103:1762-9.

152. Howell JM, Auer-Grzesiak I, Zhang J, Andrews CN, Stewart D, Urbanski SJ. Increasing incidence rates, distribution and histological characteristics of primary gastrointestinal non-Hodgkin lymphoma in a north American population. Can J Gastroenterol. 2012;26:452-6.

153. Perry AM, Warnke RA, Hu Q, Gaulard P, Copie-Bergman C, Alkan S, et al. Indolent T-cell lymphoproliferative disease of the gastrointestinal tract. Blood. 2013;122:3599-606.

154. Margolskee E, Jobanputra V, Lewis SK, Alobeid B, Green PHR, Bhagat G. Indolent small intestinal CD4+ T-cell lymphoma is a distinct entity with unique biologic and clinical features. PLoS One. 2013;8:e68343. 
155. Zivny J, Banner BF, Agrawal S, Pihan G, Barnard GF. CD4+ T-cell lymphoproliferative disorder of the gut clinically mimicking celiac sprue. Dig Dis Sci. 2004;49:551-5.

156. Malamut G, Meresse B, Kaltenbach S, Derrieux C, Verkarre V, Macintyre E, et al. Small intestinal CD4+ Tcell lymphoma is a heterogenous entity with common pathology features. Clin Gastroenterol Hepatol. 2014;12:599-608.

157. Carbonnel F, Lavergne A, Messing B, Tsapis A, Berger R, Galian A, et al. Extensive small intestinal T-cell lymphoma of low-grade malignancy associated with a new chromosomal translocation. Cancer. 1994;73:1286-91.

158. Svrcek M, Garderet L, Sebbagh V, Rosenzwajg M, Parc Y, Lagrange M, et al. Small intestinal CD4+ T-cell lymphoma: a rare distinctive clinicopathological entity associated with prolonged survival. Virchows Arch. 2007:451:1091-3.

159. Hirakawa K, Fuchigami T, Nakamura S, Daimaru Y, Ohshima K, Sakai Y, et al. Primary gastrointestinal Tcell lymphoma resembling multiple lymphomatous polyposis. Gastroenterology. 1996;111:778-82

160. Egawa N, Fukayama M, Kawaguchi K, Hishima T, Hayashi Y, Funata N, et al. Relapsing oral and colonic ulcers with monoclonal T-cell infiltration. A low grade mucosal T-lymphoproliferative disease of the digestive tract. Cancer. 1995;75:1728-33.

161. Ranheim EA, Jones C, Zehnder JL, Warnke R, Yuen A. Spontaneously relapsing clonal, mucosal cytotoxic T-cell lymphoproliferative disorder: case report and review of the literature. Am J Surg Pathol. 2000;24:296-301.

162. Carbonnel F, d'Almagne H, Lavergne A, Matuchansky C, Brouet JC, Sigaux F, et al. The clinicopathological features of extensive small intestinal CD4 T cell infiltration. Gut. 1999;45:662-7.

163. Leventaki V, Manning JT, Luthra R, Mehta P, Oki Y, Romaquera JE, et al. Indolent peripheral T-cell lymphoma involving the gastrointestinal tract. Hum Pathol. 2014;45:421-6.

164. Matnani R, Ganapathi KA, Lewis SK, Green PH, Alobeid B, Bhagat G. Indolent T- and NK-cell lymphoproliferative disorders of the gastrointestinal tract: a review and update. Hematol Oncol. 2017;35:3-16.

165. Swerdlow SH, Campo E, Pileri SA, Harris NL, Stein H, Siebert R, et al. The 2016 revision of the World Health Organization classification of lymphoid neoplasms. Blood. 2016;127:2375-90.

166. Axelsson E, Ratnakumar A, Arendt M-L, Maqbool K, Webster MT, Perloski M, et al. The genomic signature of dog domestication reveals adaptation to a starch-rich diet. Nature. 2013:495:360-4.

167. Wang G-D, Zhai W, Yang H-C, Fan R-X, Cao X, Zhong L, et al. The genomics of selection in dogs and the parallel evolution between dogs and humans. Nat Commun. 2013;4:1860.

168. Schoenebeck JJ, Ostrander EA. Insights into morphology and disease from the dog genome project. Annu Rev Cell Dev Biol. 2014;30:535-60.

169. LeBlanc AK, Breen M, Choyke P, Dewhirst M, Fan TM, Gustafson DL, et al. Perspectives from man's best friend: National Academy of Medicine's workshop on comparative oncology. Sci Transl Med. 2016;8:324-9.

170. Berghoff N, Steiner JM. Laboratory tests for the diagnosis and management of chronic canine and feline enteropathies. Vet Clin North Am Small Anim Pract. 2011:41:311-28.

171. Guzmán-de la Garza FJ, Ibarra-Hernández JM, Cordero-Pérez P, VillegasQuintero P, Villarreal-Ovalle Cl, Torres-González L, et al. Temporal relationship of serum markers and tissue damage during acute intestinal ischemia/reperfusion. Clinics (Sao Paulo). 2013;68:1034-8.

172. Terragni R, Morselli-Labate AM, Vignoli M, Bottero E, Brunetti B, Saunders JH. Is serum total LDH evaluation able to differentiate between alimentary lymphoma and inflammatory bowel disease in a real world clinical setting? PLoS One. 2016;11(3):e0151641.

173. Xenoulis PG, Steiner JM. Current concepts in feline pancreatitis. Top Companion Anim Med. 2008;23:185-92.

174. Waly NE, Stokes CR, Gruffydd-Jones TJ, Day MJ. Immune cell populations in the duodenal mucosa of cats with inflammatory bowel disease. I Vet Intern Med. 2004:18:816-25.

175. Said J. T-cell LPD of the GIT: first do no harm. Blood. 2013;122:3548-50.

176. Nijeboer P, de Baaij LR, Visser O, Witte Bl, Cillessen SAGM, Mulder CJ, et al. Treatment response in enteropathy associated T-cell lymphoma; survival in a large multicenter cohort. Am J Hematol. 2015;90:493-8.

\section{Ready to submit your research? Choose BMC and benefit from:}

- fast, convenient online submission

- thorough peer review by experienced researchers in your field

- rapid publication on acceptance

- support for research data, including large and complex data types

- gold Open Access which fosters wider collaboration and increased citations

- maximum visibility for your research: over $100 \mathrm{M}$ website views per year

At BMC, research is always in progress.

Learn more biomedcentral.com/submissions 